\title{
Семейноя экспедиция:
}

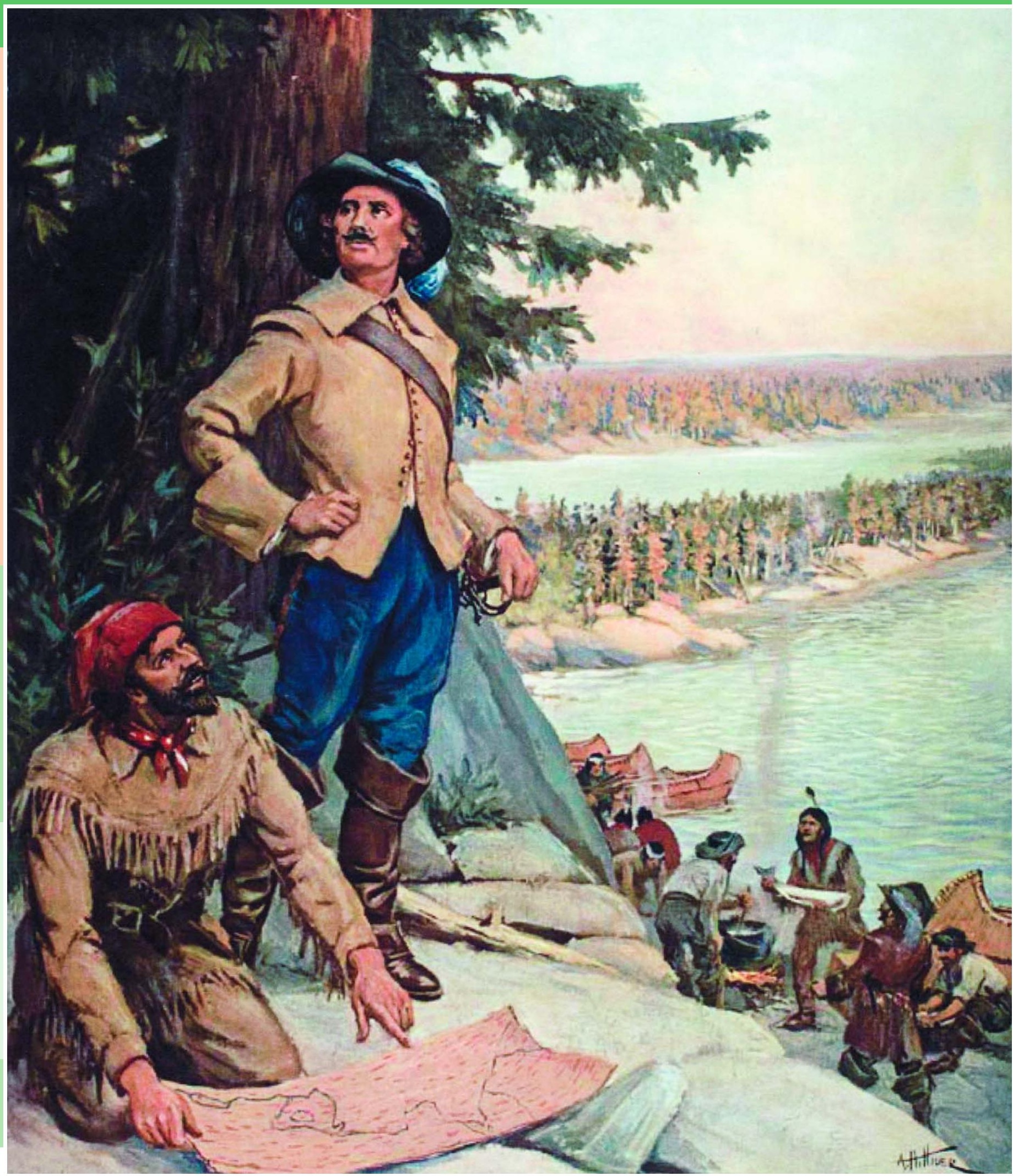




\section{Bepantoun \\ U CButhobist}

О Готье из Анжера (графство Анжу в нижнем течении Луары) известно с середины XVI века. Были среди них военные, законники и чиновники.

Старейший известный представитель Рене Готье (около 1560-1638 гг.) У него было две дочери и четыре сына: от первой жены, Жанны, - Жак Готье де ла Бланшардье (королевский советник, надзиравший за поступлением налогов и контролировавший ярмарки в Анжу, позднее мэр города Анжера) и Рене Готье де Бумуа (входил в Государственный совет); от второй жены, Перрин, - Пьер Готье де Ла Верандри (15761619 гг.), секретарь суда округа Анжер и Франсуа Готье де Лонгли.

У Пьера и Рени Готье было два сына: Адам-Пьер (1604-1670 гг.) и Жак (1606-1671 гг.)

\section{В том, чтобы породниться с одним из самых влия-} тельных семейств Новой Франции мог быть и определенный расчет: когда в следующем году Бушер подал в отставку (чтобы обустроить свое поместье Бушервиль), его место занял Рене Готье де Варенн. Впрочем, официально он числился в должности не с 10 июня 1668, а с 1672 г.

\section{Алексей Стрельцов}

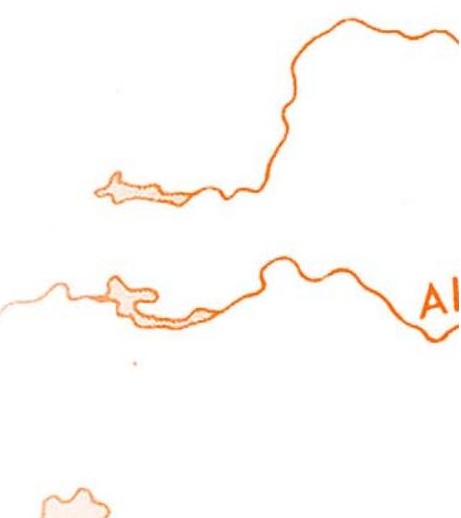

\section{Nipigon}

Fort Ste Anne
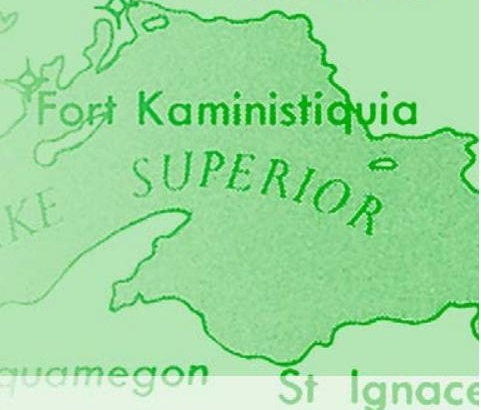

Верандри на Лесном озере.

Худ. Артур Генри Хайдер. Около 1900 г.

Национальная библиотека и архивы Канады,

Оттава.

Пьер Готье де Варенн, сьер де Ла Верандри

(1685-1749 гг.) Марка.

Канадский музей цивилизации, Оттава.
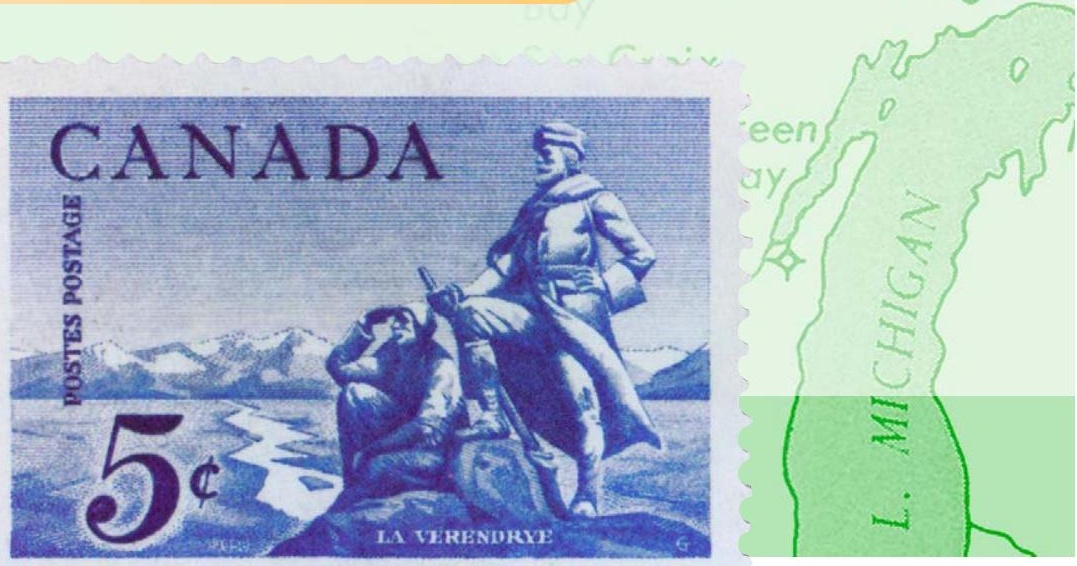


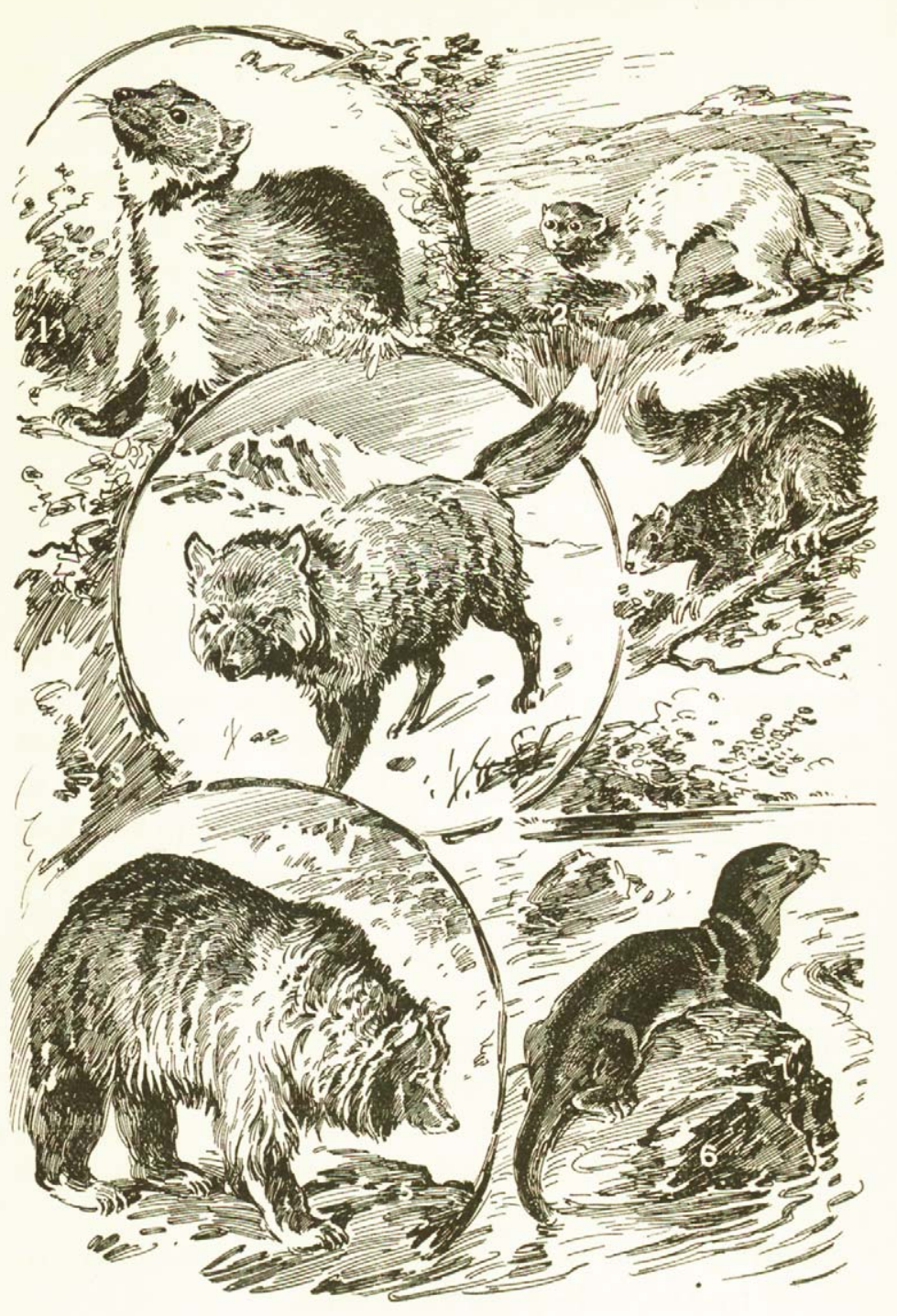

Младший, как часто случалось в дворянских семьях, принял сан и со временем стал аббатом в находившемся в тех краях монастыре Понтрон. Адам-Пьер Готье де Варенн де Ла Верандри женился на Бертране Гурдо, и стал отцом Рене Готье де Варенна и Шарля Готье де Ла Верандри (?-1697). Из имен понятно, что каждый из сыновей унаследовал одно из поместий - Варенн или Ла Верандри, но существовали ли они в действительности, и кто первым в роду заслужил герб, неясно. Почему - рассмотрим позднее.

Рене Готье де Варенн появился на свет в 1634 или 1635 году в Беконле-Гранит (возле Анжера). В сентябре 1665 года он прибыл в Канаду в составе Кареньян-Сальерского полка. Его рота была расквартирована в Труа-Ривьер. Возможно, уже в первую зиму молодой лейтенант позна- комился с местным губернатором, Пьером Бушером, и его юной дочерью, Марией-Урсулой, на которой в сентябре 1667 года и женился. В том, чтобы породниться с одним из самых влиятельных семейств Новой Франции мог быть и определенный расчет: когда в следующем году Бушер подал в отставку (чтобы
Дикие обитатели Канады:

1. Куница; 2. Горностай; 3. Лиса;

4. Белка; 5. Медведь; 6. Выдра.

Рисунок из книги Роберта Баллантайна «The young fur-traders» (Лондон, 1856 г.)

обустроить свое поместье Бушервиль), его место занял Рене Готье де Варенн. Впрочем, официально он числился в должности не с 10 июня 1668, а с 1672 года. Он принимал участие в экспедиции губернатора Курселя на озеро Онтарио и хорошо зарекомендовал себя, за что интендант Талон пожаловал ему 29 октября 1672 года поместья Варенн (218 акров) и Дю Трембле (67 акров) «сучетом хороших, полезных и похвальных услуг, оказанных Его Величеству в различных местах, в Старой и Новой Франиии». Годом позже губернатор Фронтенак пожаловал ему поместье Ла Верандри, известное также как Ла Габель (в переводе с французского - «пошлина», «налог на соль»).

Странное совпадение названий благоприобретенных и унаследованных имений наводит на крамольную мысль, что изначально предки Рене Готье «имений не имели», а использовали соответствующие названия местечек возле Бекон-леГранит как составную часть своего имени. (Можно предположить, что французские владения семьи по какой-то причине были утрачены, и канадским были даны те же имена, «тобы не нарушать отиетность», но подобное предположение нам кажется притянутым за уши).

Как бы там ни было, теперь у Рене Готье де Варенна были и земли, и расположение начальства. Впрочем, уже в 1681 году Талон писал

\section{Странное совпадение названий благо-} приобретенных и унаследованных имений наводит на крамольную мысль, что изначально предки Рене Готье «имений не имели», а использовали соответствующие названия местечек возле Бекон-ле-Гранит как составную часть своего имени. 
Скупка пушнины.

Рисунок из книги Роберта Баллантайна «The young fur-traders» (Лондон, 1856 г.) министру Кольберу: «у господина де Варенна и господина де Бушера, его тестя, по 5 каноэ и по 10 скупшиков пушнины у каждого». Что делать, денег на содержание многочисленного семейства (к 1682 году 7 детей) не хватало. Жалование губернатора составляло 1200 ливров в год, и за свой счет нужно было содержать офицера и 7 солдат гарнизона. Сельское хозяйство приносило немного: в Дю Трембле было 30 человек и 3 головы рогатого скота, в Варенне - 71 и 57 соответственно. Ла Габель был безлюден и использовался особым образом.

Интендант Мёль 28 сентября 1685 года доносил: «Месъе де Варенн, губернатор труа-Ривъер, использует свои полномочия для ведения частной торговли с индейцами в местечке с названием Ла Габель. Это запрещено указами Его Величества, разрешаюшими делать это только в ТруаРивъер. Я неоднократно выражал свое отношение по этому вопросу упомянутому господину де Варенну....

Рене Готье не уволили. Губернатор колонии Денонвиль признал, что он «оченъ достойный человек, единственный порок которого - бедность». Исправить ситуацию и нажить состояние в следующие несколько лет Рене Готье не удалось (он увеличил только потомство), и после его смерти 4 июня 1689 году семья (из 11 детей выросли 8-9) осталась почти без средств.

Младшего (из оставшихся в живых) сына, родившегося 17/18 ноября 1685 года, назвали Пьер. В 1696-1699 годах он учился в иезуитской семинарии, но предпочел карьеру военного и в 14 лет стал кадетом в колониальных войсках.

В 1704-05 годах он участвовал в Войне королевы Анныㄹ. В составе франко-индейского подразделения Пьер Готье принял участие в Рейде на Дирфильд. Жан-Батист Эртель де Рувиль собрал к югу от Монреаля 250 человек, пятую часть которых составляли французы, а остальную - абенаки, ирокезы, виадонты и покумтуки, и провел их полтысячи километров по лесам к одной из деревень в колонии Массачусетс. По пути к ним присоединилось еще 30-40 покумту-

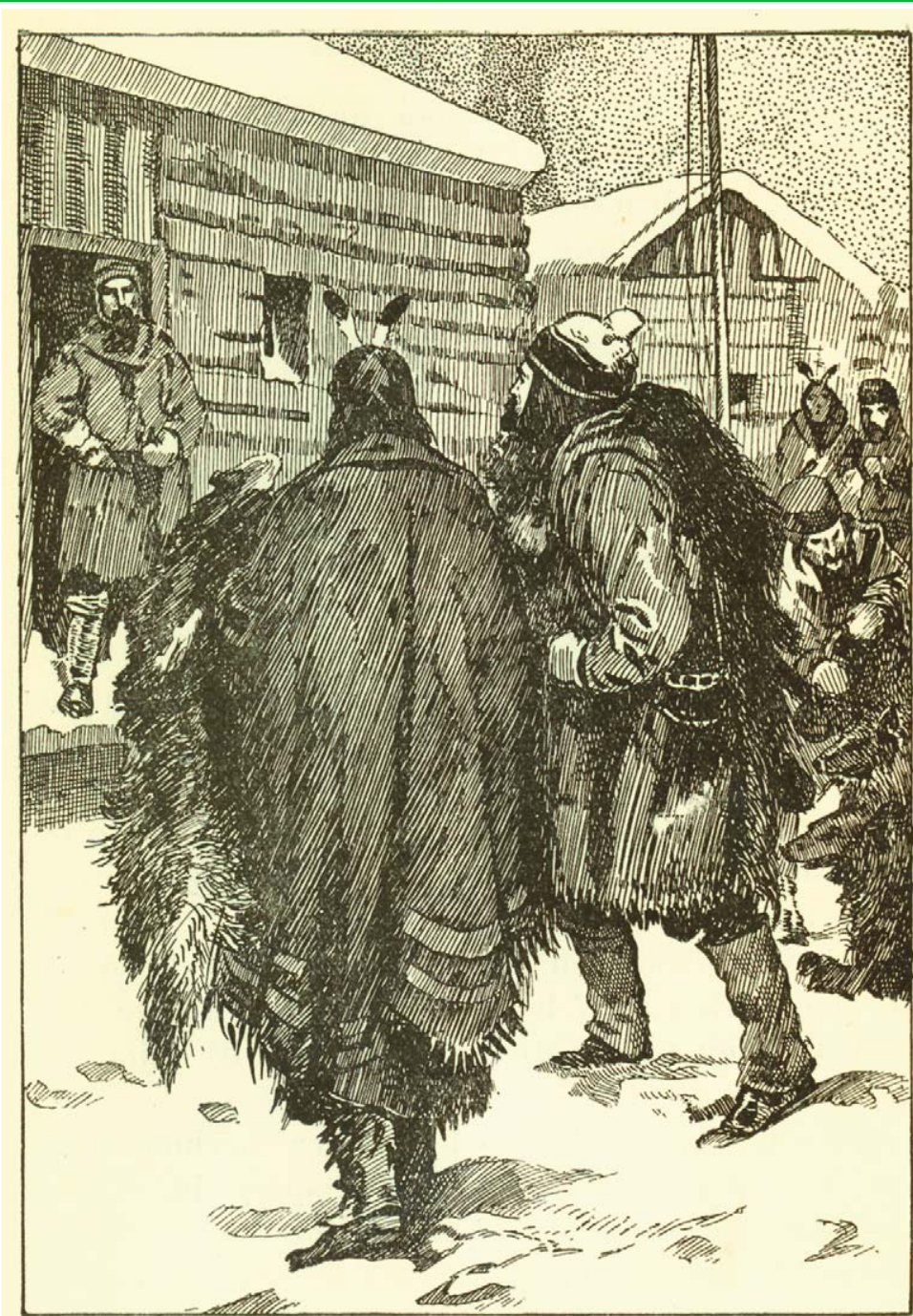

ков, горевших желанием отомстить англичанам за резню, учиненную несколькими годами раньше. Французы и их союзники напали на Дирфильд перед рассветом, 29 февраля 1704 года. Было сожжено много домов и убито 56 колонистов, о потерях нападавших точных сведений нет.

На следующий год под командованием Даниэля д'Ожера де Суберкаса Пьер Готье участвовал в неудачной атаке на английское поселение Сен-Джон на острове Ньюфаундленд.

Не видя для себя возможности выслужиться в Канаде, Пьер Готье де Варенн отправляется на «историческую родину», можно сказать, вслед за старшим братом: Луи Готье приехал туда в 1693 году, а спустя год получил чин младшего лейтенанта. В начале 1708 года Пьер был уже во Франции. Его принимают на службу в Бретонский полк в чине младшего лейтенанта: война за Испанское наследство идет полным ходом, 

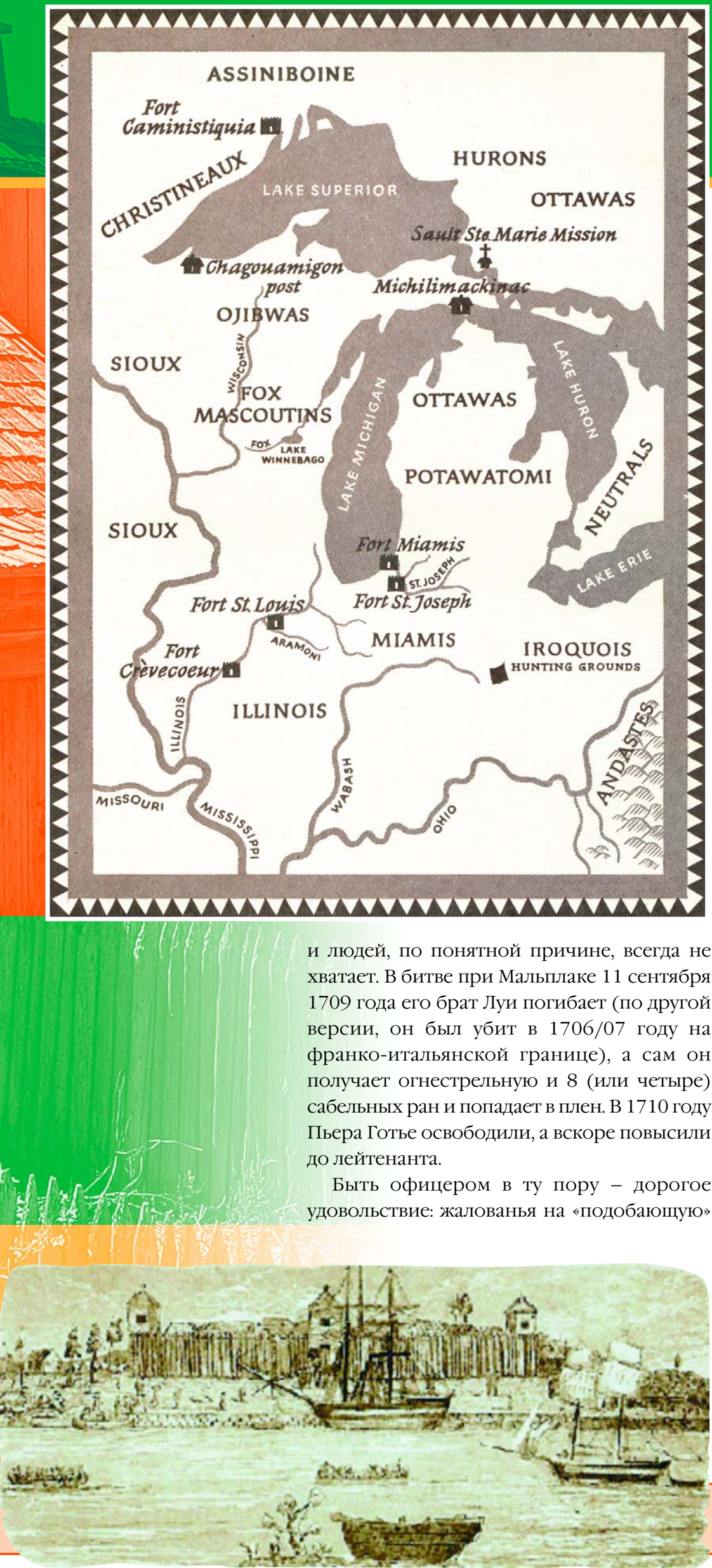

Миссии, форты и торговые посты в районе Великих озер в XVII веке.

Внизу:

Форт Каминистикиа. Гравюра XIX в. жизнь не хватало, и он обратился за разрешением вернуться в Канаду. Получив его 24 мая 1712 года, наш герой уже в июле отплыл из Франции в том же звании, в каком был: лейтенантства его лишили, а документы на звание прапорщика он подделал перед поступлением во французскую армию (впоследствии он получит этот чин при посредстве находившейся при дворе мадам де Водрё, жены губернатора Новой Франции).

24 октября 1712 года Пьер Готье женился на дочери одного из богатейших землевладельцев в тех краях, Луи Дандоно Дю Сабля, Мари-Анн, с которой обручился перед отплытием. Приданое - 2000 ливров и островки Иль-о-Ваш (Коровий остров) и Иль-Дюпа на озере Сен-Пьер, недалеко от Труа-Ривьер.

Казалось, Пьера Готье ждет тихая жизнь колониста, возделывающего землю и растящего детей - четырех сыновей и двух дочерей. Но, в действительности, все обстояло не так уже радостно - с участка площадью 38 акров семью из 8 человек не прокормить, и хотя были другие источники дохода (с имения Трамбле, жалование прапорщика, а в 1715 году исполняющий обязанности губернатора Клод де Рамезе (1659-1724 гг.) предоставил ему разрешение несколько недель в год торговать с индейцами в Ля Габель на реке Сен-Морис), Пьер Готье едва сводил концы с концами. Ему уже 40, и он начинает задумываться о том, как бы вернуть себе чин лейтенанта..

Все меняется в 1726 году. Его старшего брата Жака-Рене Готье (1677-1757 гг.) назначают командиром «Северного пункта» обширной территории к северу от озера Верхнее с центром в форте Каминистикиа (современный Тандер-Бей); еще два торговых поста расположены возле устья реки Ниппигон и Мишипикотен, возле нынешнего городка Вавы, севернее Су-Сент-Мари, по которой (а также по рекам Миссинайби и Мус) можно добраться из озера Верхнее до залива Джеймса².

Жак-Рене Готье не сидит сложа руки, нанимает людей, занимает у купцов деньги на закупку товаров. Своим помощником он де- 
лает Пьера Готье, а когда в 1728 году начинается Вторая война фокс (приведшая к почти полному уничтожению племени) и Жак-Рене отправляется в поход, тот берет в свои руки бразды правления.

Тогда же Пьер Готье де Варенн де Ла Верандри (далее - Верандри, А.С.), оказавшись на краю известной части континента, начинает задумываться о том, что находится дальше на западе.

По тогдашним представлениям, там была возвышенность, за которой текла река Запада, несущая свои воды в «Западное», или «Закатное» море, - так называли залив, который должен был глубоко вдаваться в континент со стороны Тихого океана. В 1688 году Жак де Нуайон (1668-1745 гг.) поднялся по реке Каминистикиа и достиг Текамамиуана - озера Рейни («Дождливое») на границе нынешних провинции Онтарио и штата Миннесота и одноименной реки. Он стал первым европейцем, пересекшим границу лаврентийского водораздела. От индейцев ассинибойнов он слышал про озеро Виннипег и Ред-Ривер («Красную реку») и решил, что Западное море расположено возле Лесного озера (добрался ли он до него - доподлинно неизвестно), примерно на той же широте, что и озеро Виннипег, а искомая река река Виннипегон. Казалось, что Западное море совсем рядом, и картографы Клод и Гийом Делиль придерживались того же мнения. Регент Филипп, герцог Орлеанский был также заинтересован в этом географическом открытии, так как по Ут-

${ }^{3}$ Существует странная связь между ним и героем нашего рассказа: оба родились в Труа-Ривъер. Вскоре после рождения сына родители Жака переселились в Бумервиль - имение деда Пьера Готье. В 1704 году Жак де Нуайон женился на Абигайл Стеббинс из Дирфильда, находился там во время вымеупомянутого рейда, и был взят в плен.

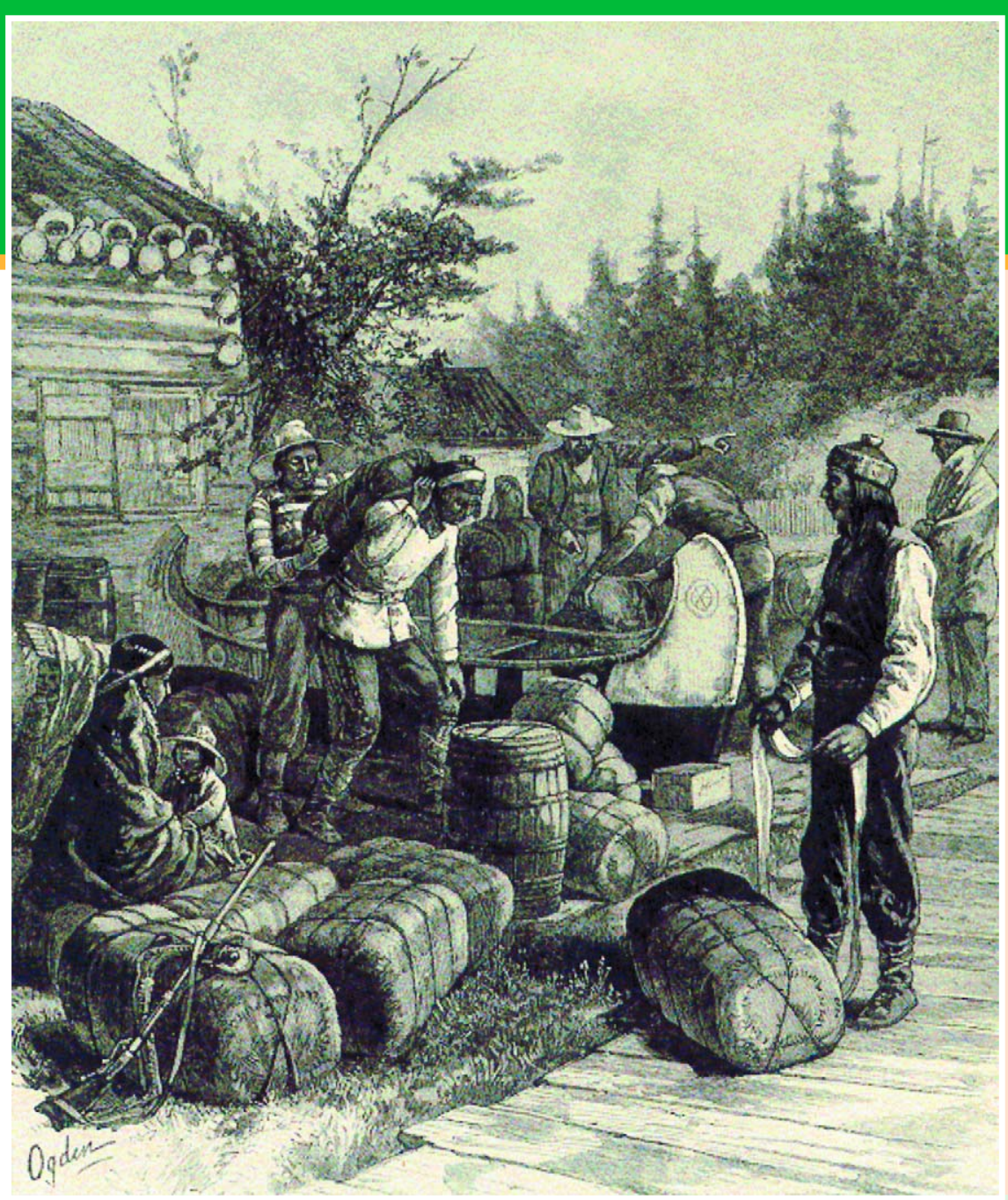

рехтскому миру 1713 года Франция лишалась прав на Гудзонов залив, а с ним и пушных богатств этого края.

Захария Робютель де Ла Ну (16651732/33 гг.), офицер колониальных войск, попытался это проверить. В 1717 году он отправился во главе экспедиции с 8 каноэ на запад, с поручением от губернатора Водрё основать три торговых поста, откуда можно было продолжить движение на запад. Он основал форт Каминистикиа, над которым начальствовал до 1721 года, но продвинуться дальше не смог из-за враждебности индейцев.

Разобраться и найти путь к Тихому океану поручили отцу Пьеру-Франсуа-Ксавье Шарлевуа (1682-1761 гг.) В 1721-1722 годах тот проплыл на каноэ по Великим озерам, а затем вниз по Миссисипи, и добрался до
Жак-Рене Готье не сидит сложа руки, - нанимает людей, занимает у купцов деньги на закупку товаров. Своим помощником он делает Пьера Готье, а когда в 1728 г. начинается Вторая война фокс (приведшая к почти полному уничтожению племени) и Жак-Рене отправляется в поход, тот берет в свои руки бразды правления. 


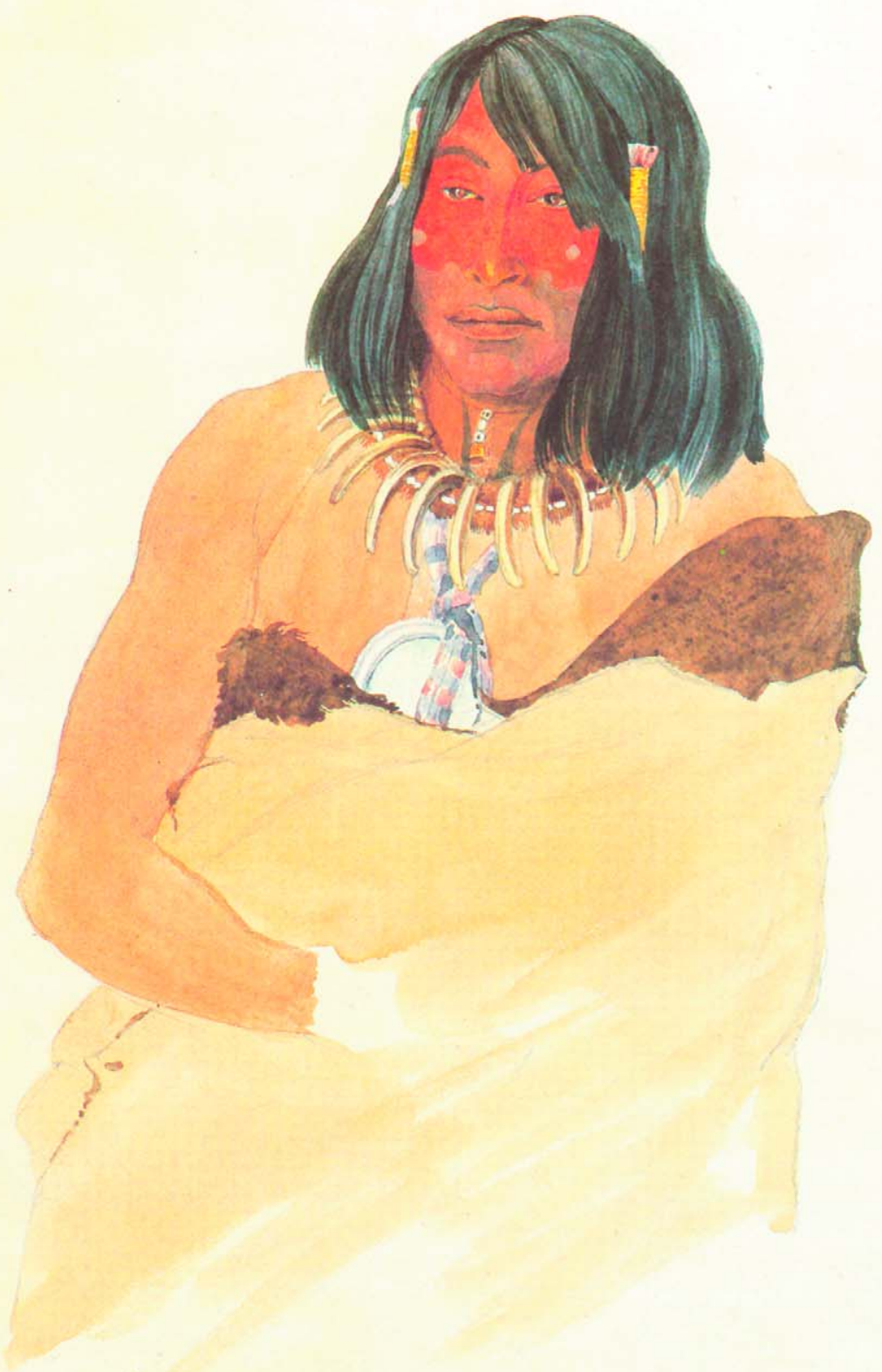

тается, что трапперы и раньше доходили до него, но точных данных нет) и окрестных реках. Индеец-проводник из племени кри по имени Ошага из собственного опыта и по рассказам соплеменников нарисовал на куске бересты три пути по воде из озера Верхнее в озеро Виннипег: первый - от Фон дю Лак (дословно «низ озера» - южная оконечность озера Виннебаго), второй - по реке Нантуаган, третий - по реке Каминистикиа.
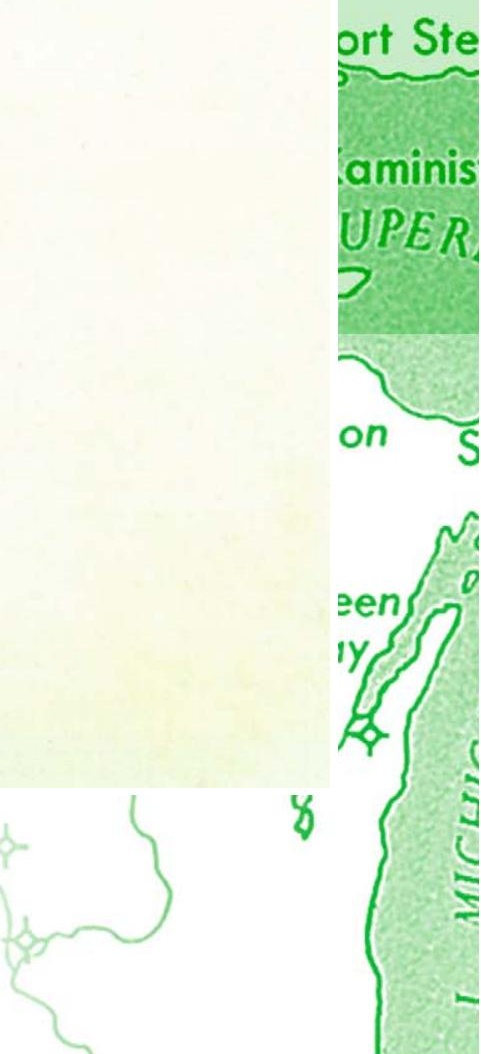


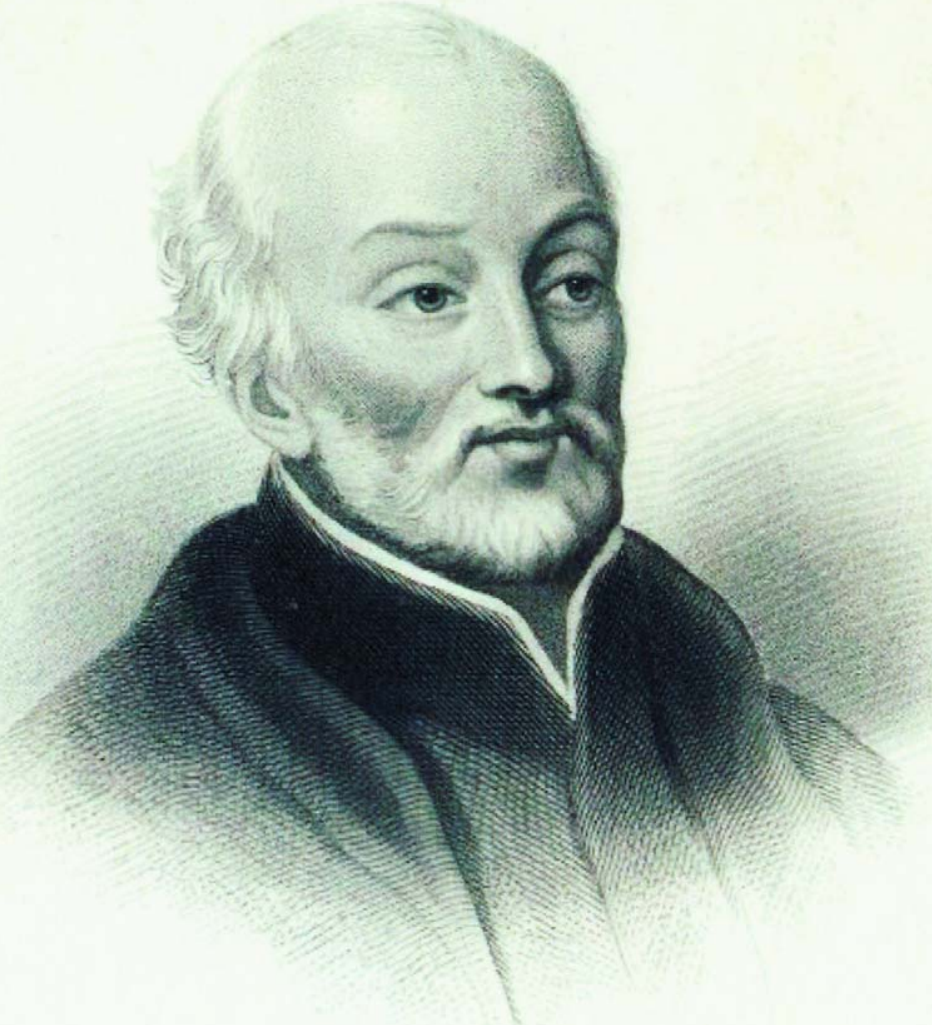

После этого у Верандри сложилось несколько отличное от идей Шарлевуа представление о Западе: искомая цель находилась много западнее озер Манитобы.

В 1728 году Верандри встретил в форте Микилимакинак иезуита Никола Дегонно, воз-

вращавшегося в Квебек из миссии в стране сиу. Тот заинтересовался идеями Верандри и обещал передать сведения и карту, на которой были нанесены озера, водоразделы, пороги и волоки, с указанием точных мест, губернатору. В 1730 году Верандри сам отправляется в Квебек и встречается с губернатором Шарлем де Боарнуа. Подробности плана в октябре того же года губернатор Боарнуа и интендант Новой Франции Жиль Окар представили в совместном донесении морскому министру Морепо: «Сравнивая ... марируты ... следует предпочесть путь по реке Нантуаган ... Правда, на ней сорок два волока, тогда как на реке Каминистикиа только двадиать два, но с другой стороны, на ней нет порогов, тогда как на последней их двенадиать, два из которых длинные имелководные. Кроме того, путь прямой ина треть короче. Водораздел тянется от силь на 50 лье, а после 70 лье идет уклон... Наконеи, несиотря на все волоки, по уверениям дикарей, путь будет легким, и мь доберемся от озера Верхнее до озера Текамамиуа в худшем случае за двадиать дней, а оттуда за четыре дня до Лесного озера, а через десять дней до озера Виннипег».

Оба эти чиновника заявили о намерении следующей весной отправить Верандри для строительства торгового поста на озере Виннипег. Это способствовало бы обнаружению Западного моря и развитию торговли мехом, поскольку тот район был богат пушным зверем. И хотя министр дал санкцию, отец Шарлевуа возражал, опасаясь (справедливо), что торговые интересы возобладают над исследовательскими.

\section{Основные средства Верандри пришлось занимать} у купцов. Всю весну 1731 г. он провел в хлопотах. В результате было создано «Товарищество девяти», куда вошли: он сам, старший сын Жан-Батист и племянник (сын сестры Мари-Рене), Кристоф Дюфро де Ла Жемере (1708-1736 гг.), которого Верандри сделал своим помощником; купцы Луи Амелен, ЛоранЭсташ Амелен Шатовьё, и Иньяс Амелен-младший; кузнец и оружейник Никола Сарразен и еще двое. 


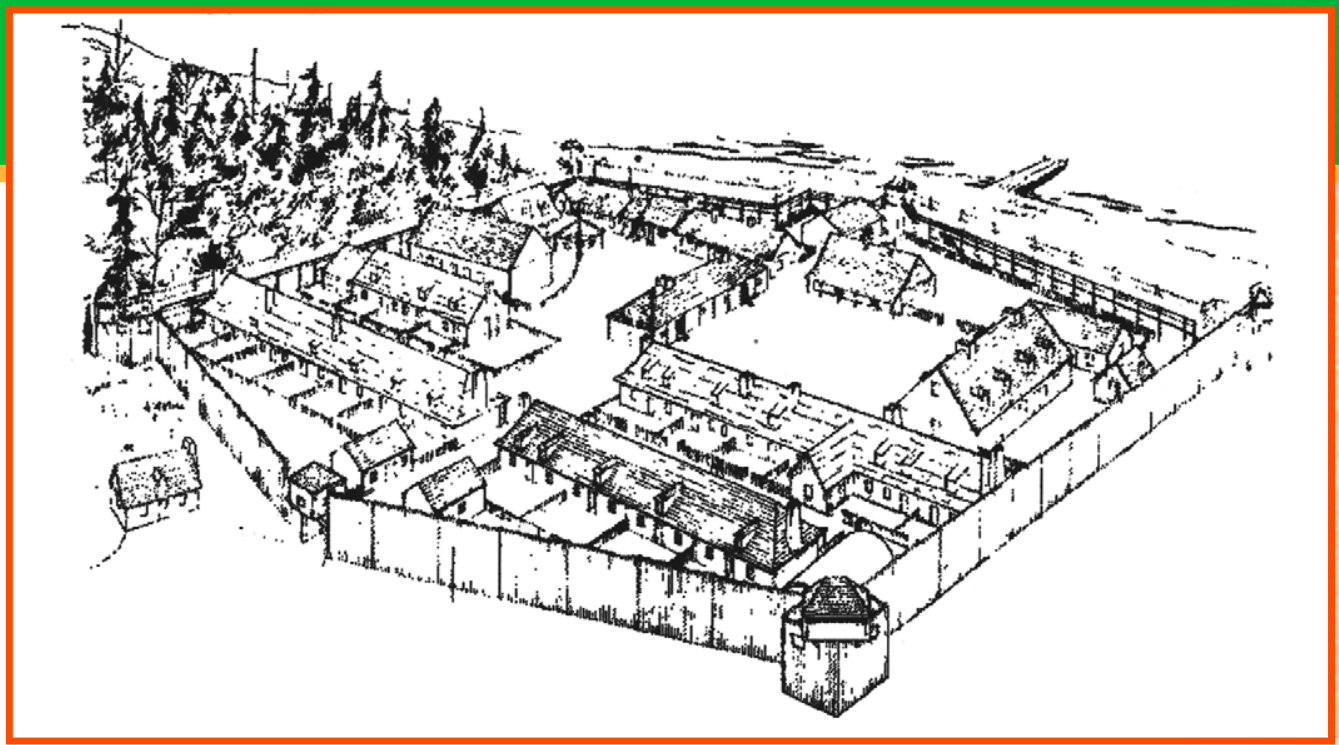

Морепо, больше заинтересованный в открытиях, выделил из казны лишь 2000 ливров на покупку подарков индейцам. Основные средства Верандри пришлось занимать у купцов. Всю весну 1731 года он провел в хлопотах. В результате было создано «Товарищество девяти», куда вошли: он сам, старший сын Жан-Батист и племянник (сын сестры Мари-Рене), Кристоф Дюфро де Ла Жемере (1708-1736 гг.), которого Верандри сделал своим помощником; купцы Луи Амелен, Лоран-Эсташ Амелен Шатовьё, и Иньяс Амелен-младший; кузнец и оружейник Никола Сарразен и еще двое. Члены товарищества получали привилегию на торговлю мехами сроком на три года: территория между озером Верхнее и Виннипег - это «край лосей и кунии, а бобров там столько, что индейцы их мало ценят, и продаюот англичанам только самые больиие шкурки", - записал Верандри в журнале в 1729 году; в привилегии ни словом не упоминалось об открытии «Западного моря».

8 июня 1731 года Пьер Готье, с сыновьями Жан-Батистом, Пьером и Франсуа и 50 спут- никами отправились из Монреаля. Вот как он сам описывал это в отчете 1744 года: «я уехал из Монреаля 8 июня 1731 года, намереваясь выказать преданность делу, коему я посвящу все чаяния». В Макино к ним присоединился иезуит Шарль-Мишель Мезегер.

Проводником Верандри был индеец-кри Ошага, который провел его от западного берега озера Верхнее до реки Пиджен («Голубиная»). 26 августа путешественники достигли Гранд-Портиджа («Большого волока») - западной оконечности озера Верхнее, в 70 километрах к юго-западу от Каминистикиа. Здесь люди, измотанные дорогой и страшась дальнейших тягот, отказались идти далее, но Верандри и отец Мезегер смогли убедить самого храброго продолжить путь вместе с Жаном-Батистом Готье и Кристофом Дюфро: «26 августа мы прибыли в ГрандПортидж на озере Верхнее ... 27-го все наши люди, испугавшись длины волока - 3 лье (14 км.), взбунтовались и потребовали, чтобы я повернул назад, но с помощью нашего отиа-миссионера я смог убедить одного из тех, кого нанял, отправиться

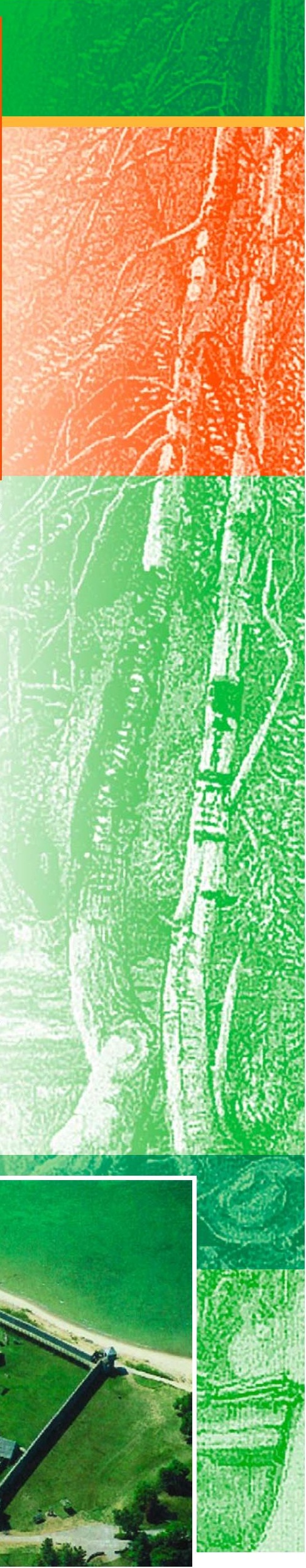

HISTORY illusluated 


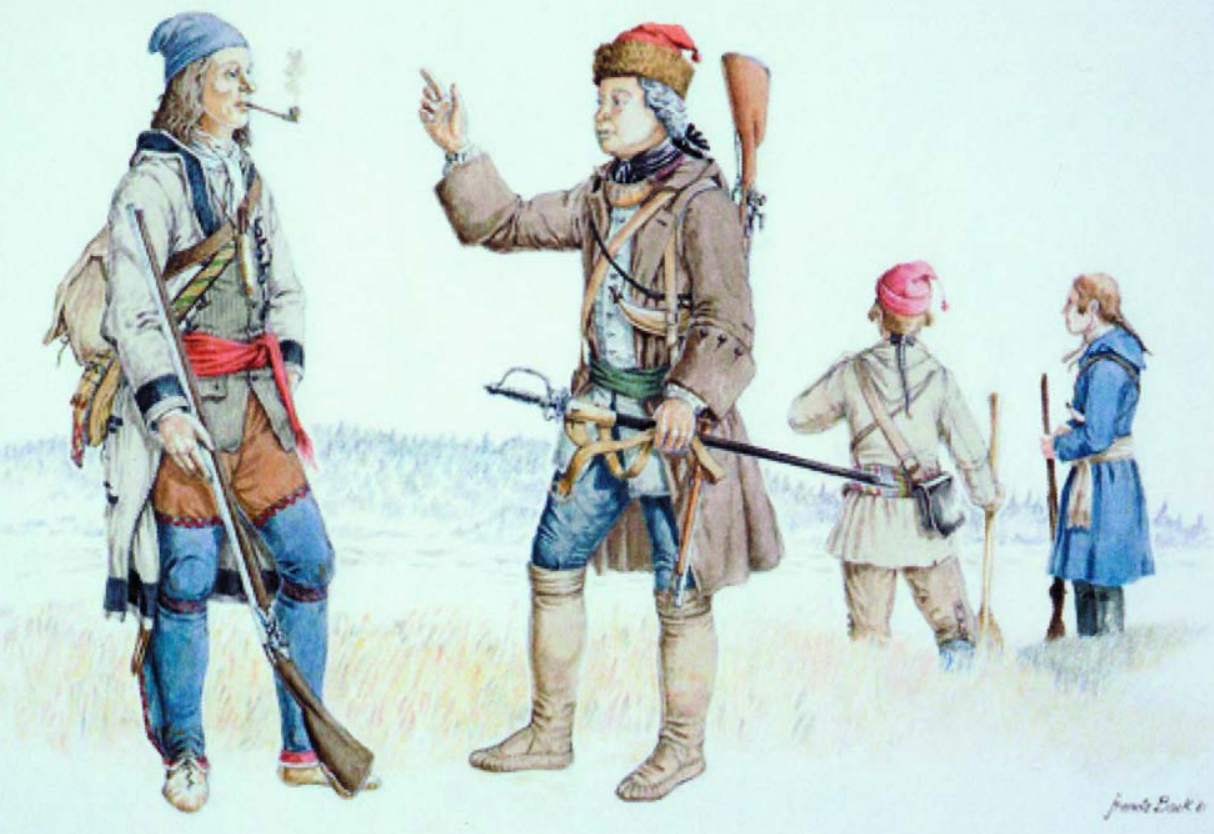

\section{Приближалось холодное время года, и было опасно} идти в края, где бы им могло не хватить продовольствия; «тем не менее, господин де Ла Верандри отправил господина де Ла Жемере с тремя средних размеров каноэ, и ... с тремя другими, кто последовали за ним до стока из озера Текамамиуан у входа в реку, впадающей в Лесное озеро, где и перезимовал ...»

с моим племянником Ла Жемере (моим помошником) имоим сыном основать пост на озере Рейни. Уменя достало всего, чтобы снарядить четыре средних каноэ... дал им хорошего проводника». В октябре 1732 года Боарнуа писал: «Я получил писыма от господина де Ла Верандри, который руководит экспедицией по открытию Западного моря, и от преподобного отиа Мезегера, который сообщил мне, что нанятые люди были обескуражены протяженностью волока от Нантагуа [составивиего] 14 километров».
Но объяснил зимовку в Каминистикиа он по-другому: приближалось холодное время года, и было опасно идти в края, где бы им могло не хватить продовольствия; жтем не менее, господин де Ла Верандри отправил господина де Ла Жемере с тремя средних размеров каноэ, и ... с тремя другими, кто последовали за ним до стока из озера Текамамиуан у входа в реку, впадающей в Лесное озеро, где и перезимовал ... ».

Миновав немало озерков и речушек, они дошли до озера Рейни, где основали форт 


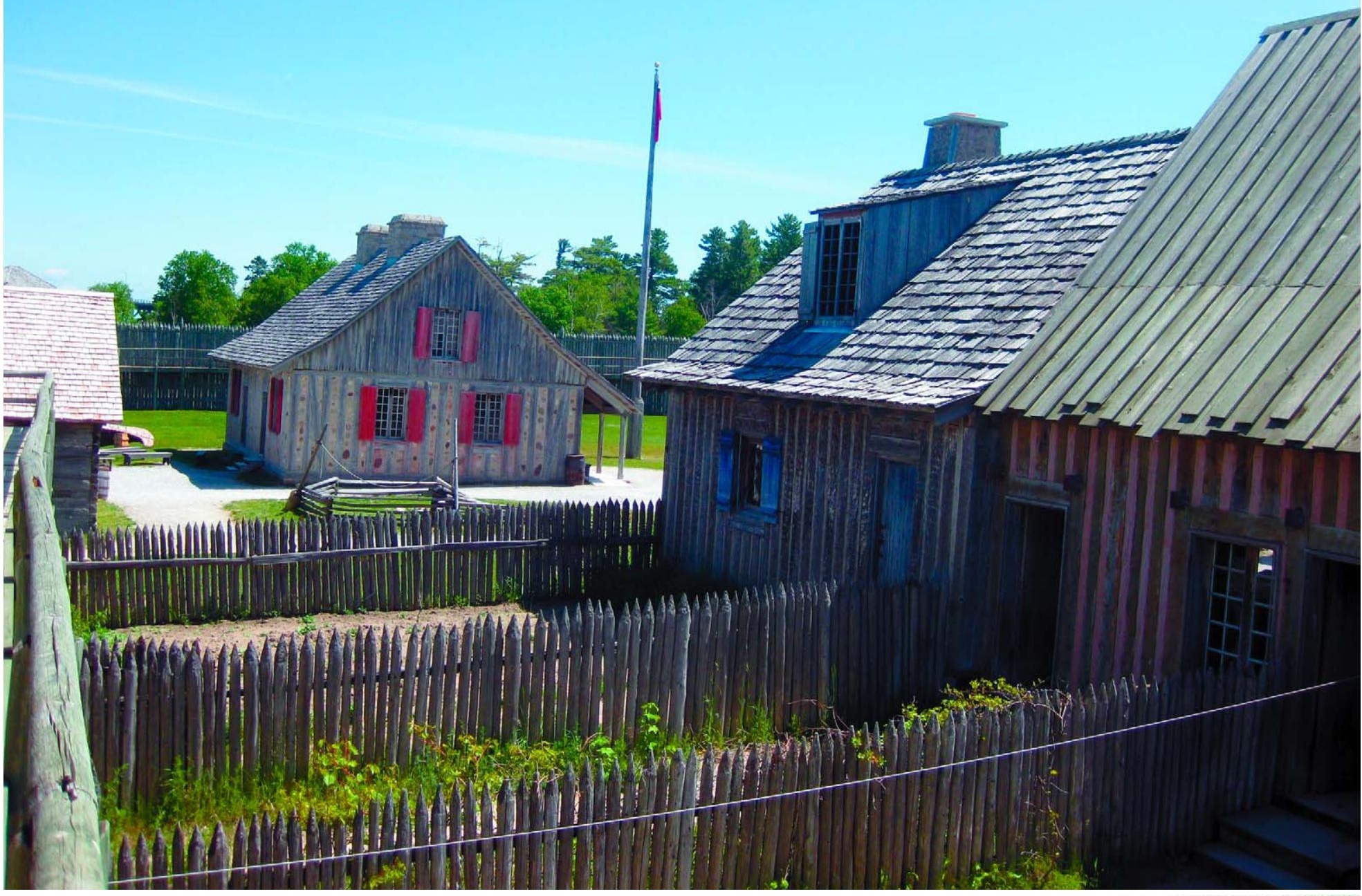

Сен-Пьер (по названию часовни, в которой крестили Жана-Батиста). Основной отряд тем временем вернулся в Каминистикиа «на зимние квартирь». Зимовка в Каминистикиа нанесла Верандри большой убыток - пришлось платить нанятым людям «за простой», у него на руках оставались товары и не было шансов возместить потери

«29 мая следуномего года, когда вернулись каноэ, посланные мной в глубъ территории, - писал Верандри, - я послал своего старшего сына доставить в Макино небольиой груз мехов и привезти товары, которые должны были прибыть из Монреаля. 8 июня мы отправились, вместе с отщом-миссионером, племянником и двумя сыновъями, на 7 каноэ, далее. 14 июля прибыли в форт Сен-Пьер. С нами было свыме 50 каноэ с дикарями». Два отряда объединились и, в сопровождении 50 каноэ индейцев кри и ассинибойнов, двинулись к Лесному озеру, из которого, предположительно, вытекала Западная река. Здесь был построен форт
Сен-Шарль, ставший на несколько лет «штабом» Верандри.

Весной 1733 года он послал Жемере и Жана-Батиста к озеру Виннипег, чтобы найти удобное место для строительства торгового поста. Увы, в путь они вышли слишком рано: лед еще не сошел, и молодые путешественники остановились в паре десятков километров от цели. Жан-Батист остался на месте, где построил маленький форт, а Жемере вернулся в форт Сен-Шарль. Вскоре Верандри послал его в Квебек. 20 сентября тот был уже в Монреале (в том время, как Жан-Батиста отправили в форт Сен-Пьер встречать каноэ из Монреаля), а откуда направился в столицу колонии. Здесь он, на правах «правой рукu» своего дяди, встретился с губернатором Боарнуа, чтобы обсудить финансовые и прочие вопросы экспедиции: 43 тысячи ливров были уже истрачены, а доходов было явно недостаточно. Не согласится ли корона выплачивать по 10 тысяч ливров в ближайшие 3 года? 


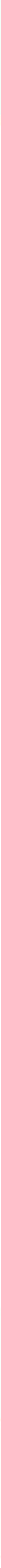




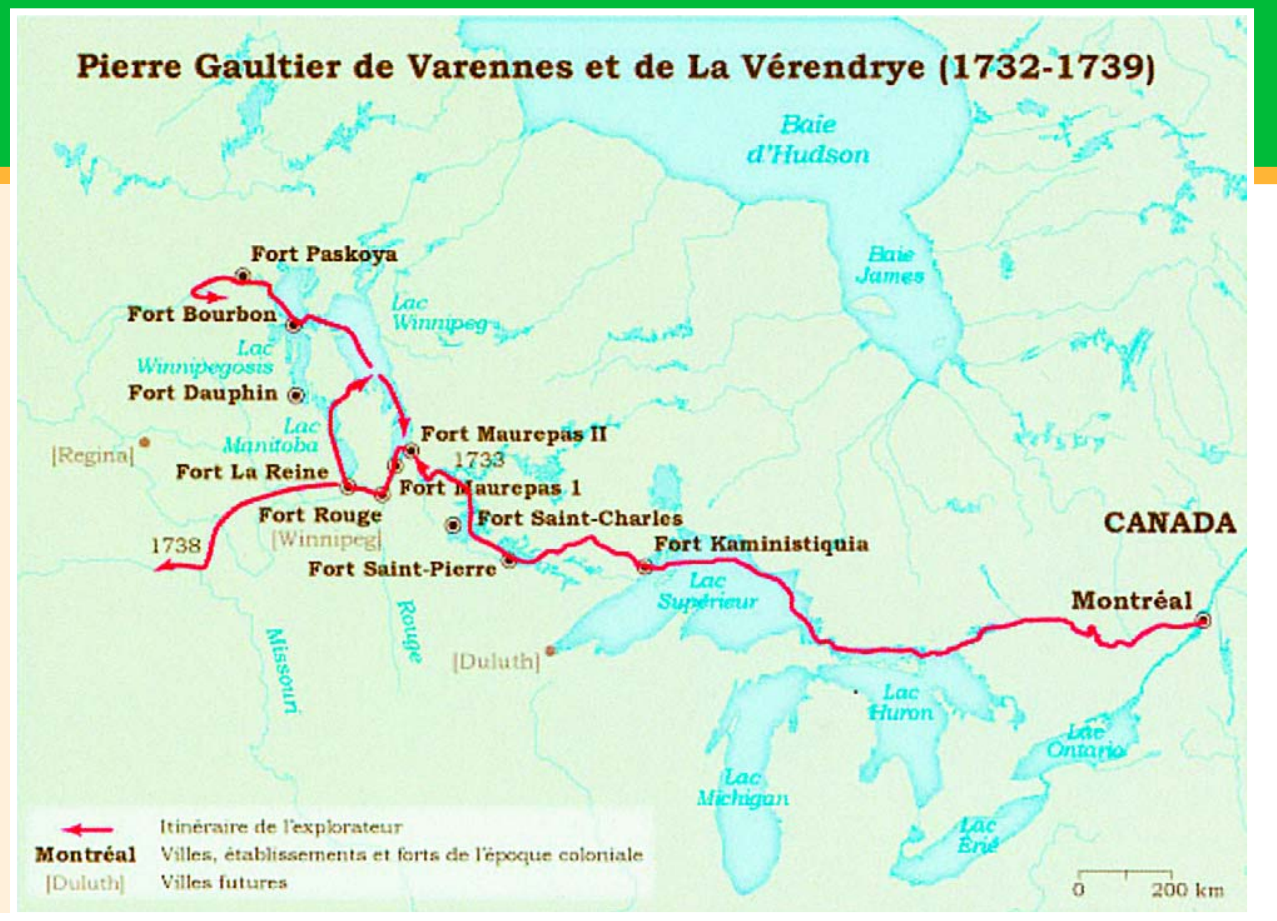

ции, Жемере невольно совершил два крупных промаха: Морепо уверился, что достичь цели сравнительно просто, в свете чего любые задержки Верандри становились непонятными; не исследовав озеро Виннипег и окрестности и полагаясь исключительно на рассказы индейцев, планировалось вести поиски в районе Миссури, которая впадает в текущую на юг Миссисипи, и к пути на запад имеет весьма отдаленное отношение.

Пока сын и племянник занимались исследованиями, Верандри вел дела с индейцами. Ситуация в этих краях напоминала ту, с которой столкнулся Шамплен за сто лет до того: поскольку Квебек находился на землях алгонкинов и монтанье, французы приняли их сторону в войне с ирокезами. Но Верандри не поддержал ассинибойнов и кри, на землях которых находились форты Сен-Пьер и Сен-Шарль, против сиу и оджибве, так как последние

Каноэ в тумане, озеро Верхнее. Худ. Франсис Энн Хопкинс. 1869 г. Музей Гленбоу, Калгари.

5 Упоминаемых Верандри таинственных «монсони» историкам пока не удается распознать. Предполагают, что это могли быть некоторые племена кри, живиие на северо-востоке современной провинции Онтарио или даже шайены. - Прил. ред.
Маршрут путешествий Пьера Готье де Варенна, сьера де Ла Верандри в 1732-1739 гr.

служили боеприпасы. В качестве «военного наблюдателя» с правом голоса с ними отправился и ЖанБатист Готье. Впрочем, как только стало понятно, что целью нападения будут именно речные сиу, он оставил спутников.

Спустя несколько дней, 27 мая 1734 года, Верандри направился в Монреаль. «Я отправляюсь в Макино и, возможно, в Монреаль, чтобы донести ваше послание... и достать то, чего нам здесь не хватает табак, ружья и котелки, которые вы получите в обмен на куниц и рысей, а не на бобровые икуры, которые станете использовать для других своих надобностей..., - заявил он на вышеупомянутой встрече с индейцами. Были и другие дела: он хотел досрочно расторгнуть договор с Луи Амеленом, которому был должен 7768 ливров, узнать ответ Морепо на его просьбу о «госфинансирова нuи» и порадовать губернатора известием, что форт на озере Виннипег скоро будет построен: 11 мая вернулись посланные им люди с известием, что они достигли озера и нашли удобное место в нескольких километрах от устья Ред-Ривер Уже в июне стараниями Жана-Батиста был построен форт, получивший имя Морепо (в 10 км к северу от нынешнего городка Селкерк).

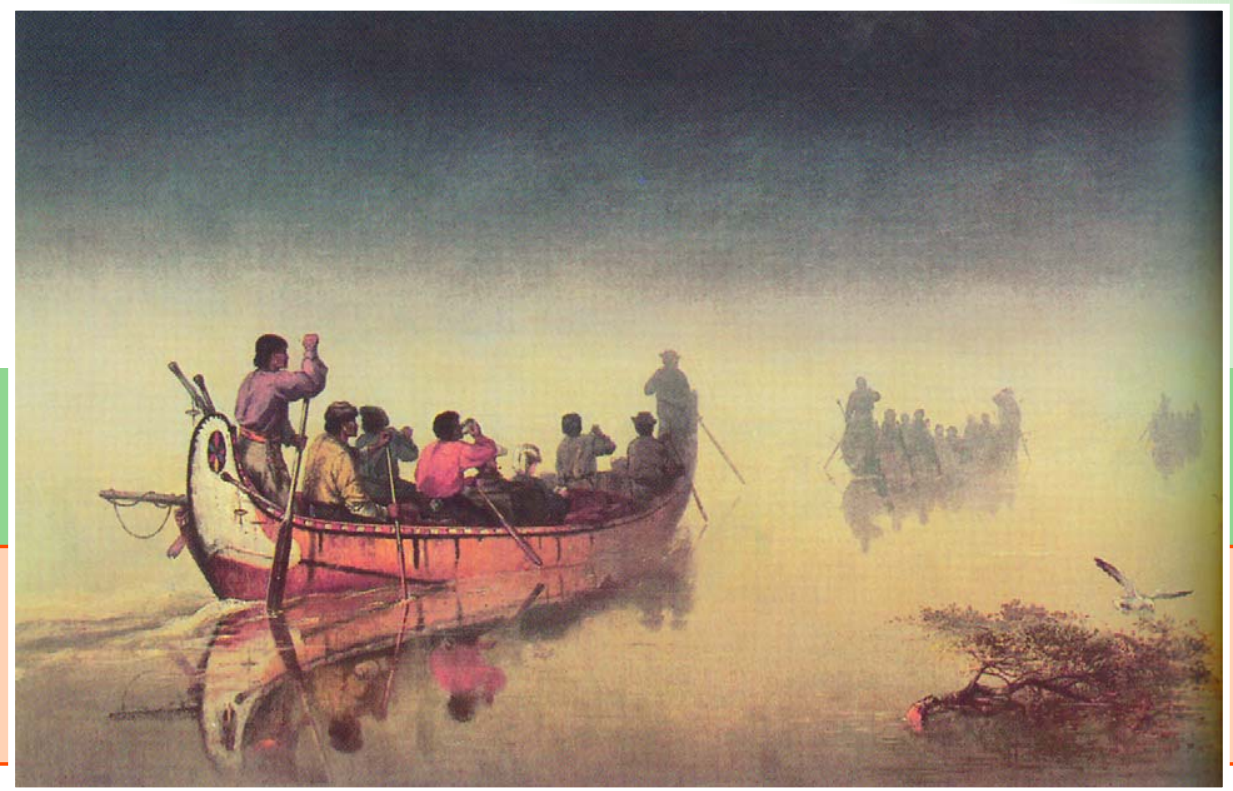




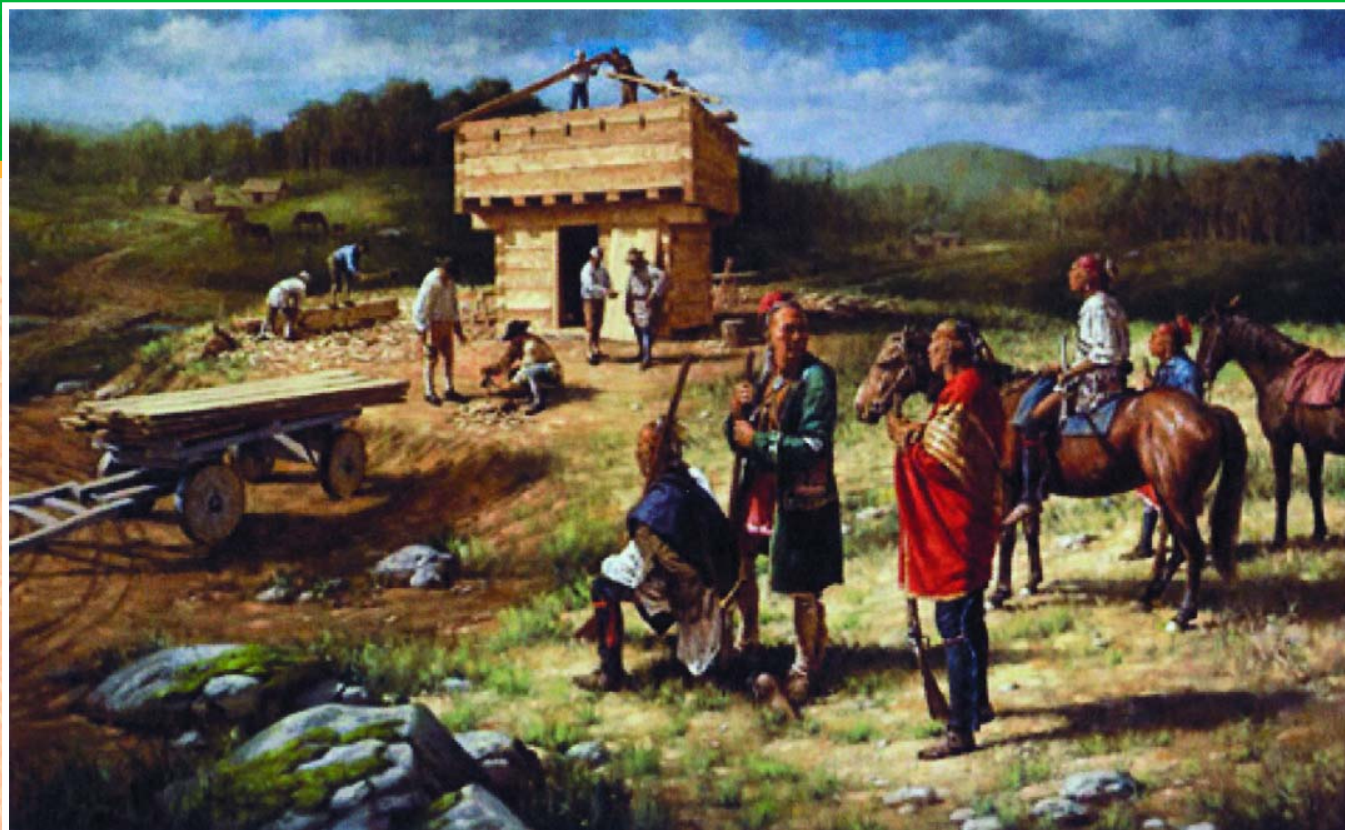

Меняющаяся страна. Худ. Роберт Гриффинг.

Зимняя торговля. Худ. Роберт Гриффинг. $\Rightarrow$

В Монреале добрых новостей не было: партнеры не горели желанием выделять дополнительные средства, начав сомневаться в әффективности инвестиций, а король указал, что предприятие должно быть самофинансируемым за счет торговли пушниной. В сложившейся ситуации губернатор Боарнуа не спешил самоустраниться, а искал решение, которое удовлетворило бы и министра, и отвечало интересам колонии. В результате Верандри передал свои посты партнерам сроком на три года для ведения торговли, в обмен на жалование в 3000 ливров в год, дабы он мог заняться открытиями.

18 мая 1735 года было образовано новое товарищество, главную роль в котором играли Жан-Батист Легра и Жан-Мари Нолан, младший брат одного из богатейших монреальских купцов, Шарля Нолана Ламарка, который и сам посылал своих людей на запад.
21 июня 1735 года Ла Верандри, вместе с младшим сыном Луи-Жозефом (17171761 г.) и иезуитом Жан-Пьером Олно (1705-1736 г.), замещавшим отца Мезегера, отправился в путь. 23 октября они были уже в форте Сен-Шарль, где их ждала первая неприятная новость: заболел Жемере, начальник форта Морепо. Его перенесли в форт Сен-Шарль, где он и скончался 10 мая 1736 года.

Купцы, занятые торговлей, не выполняли взятых на себя обязательств по снабжению фортов, и весной 1736 года Верандри послал отряд из 21 человека под командованием старшего сына Жана-Батиста в форт Каминистикиа за продовольствием. 8 июня, когда они находились на одном из островов Лесного озера, на них напали сиу (по некоторым сведениям, числом до 130), горевшие желанием отплатить за поход 1734 года: «В этом бедствии я потерял сына, святого 


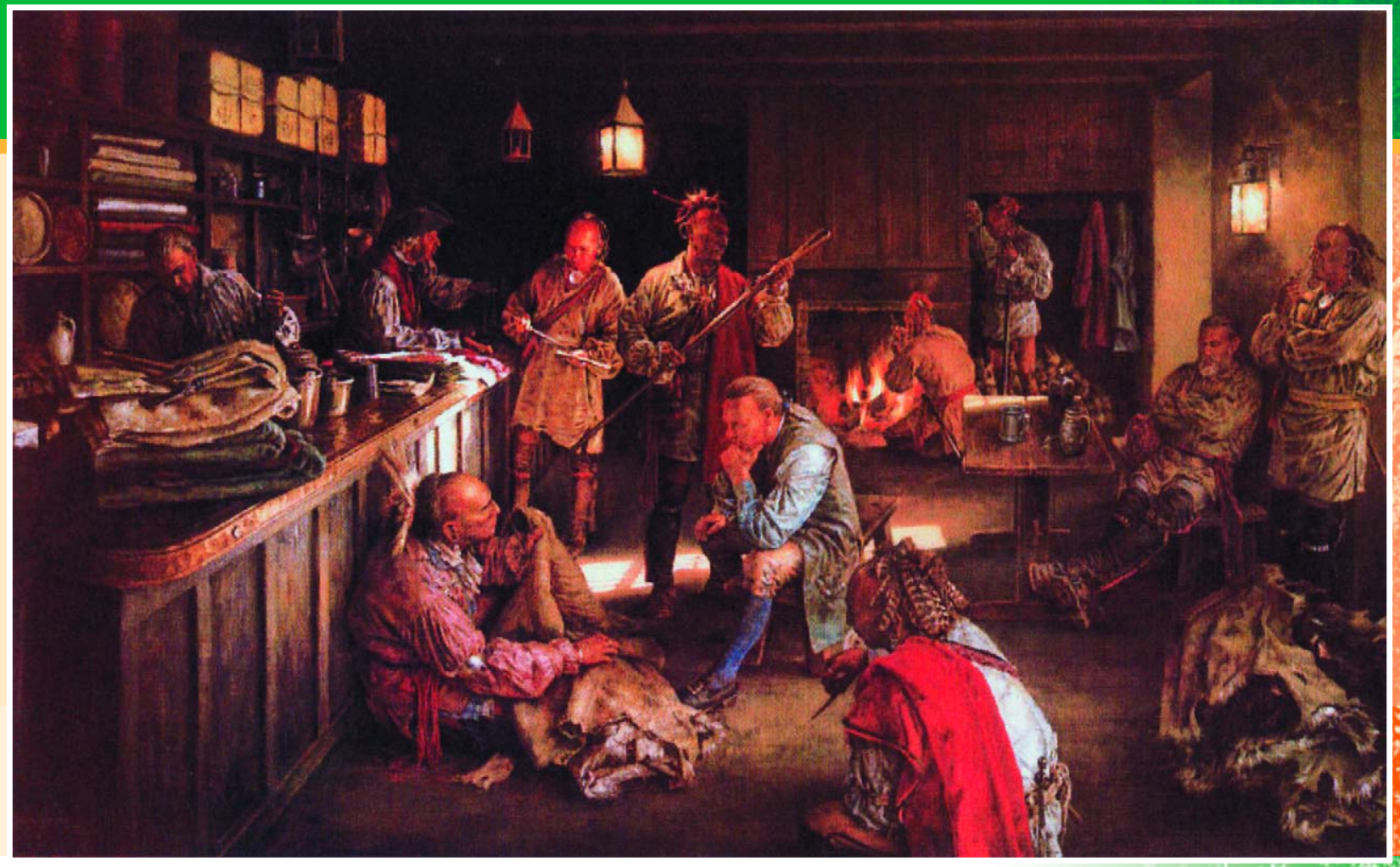

отиа [Олно] и всех своих франиузов, о чем буду скорбеть всю жизнь", - писал Верандри.

Член партии, обнаруживший останки, так описывает их: «Трупы лежали по кругу, головы были отрублены и завернуты в бобровые икуры. Большинство из них оскальпированы. Ла Верандри лежал на животе. Спина его была иссечена ножами, в бок забит кол, головы нет, на самом теле лежат леггины (ноговицы, которые индейцы носили вместо штанов - А.С.) $u$ иглы дикобраза (они использовались для вышивки на леггинах - А.С.)» Когда индейцы кри сообщили Верандри о резне, он распорядился привезти головы 19 французов и обезглавленные тела сына и отца Олно в форт Сен-Шарль. Они были похоронены в грубовытесанных гробах под алтарем часовни, а головы - в канаве по соседству.

Гибель этого отряда имела и другие последствия: осенью Луи-Жозеф Готье отправился к озеру Виннипег, намереваясь оттуда продолжить путь в страну манданов, но изза отсутствия продовольствия вынужден был отказаться от этого плана.

Верандри же пришлось успокаивать ассинибойнов, кри и «монсони», готовых отомстить за смерть французов и развязать столь нежелательную войну, а затем он с Пьером Готье-младшим присоединился к младшему сыну.

В феврале 1737 года Верандри достиг озера Виннипег. Он мог бы направиться далее, к манданам, благо время позволяло и индей-

Купцы, занятые торговлей, не выполняли взятых на себя обязательств по снабжению фортов, и весной 1736 г. Верандри послал отряд из 21 человека под командованием старшего сына Жана-Батиста в форт Каминистикиа за продовольствием. 8 июня, когда они находились на одном из островов Лесного озера, на них напали сиу (по некоторым сведениям, числом до 130), горевшие желанием отплатить за поход 1734 г. 
Форт Сен-Шарль. Историческая реконструкция. и Франсуа, братьев Нолан и 25 ассинибойнов он выступил к манданам. В пути к нему присоединились еще несколько сотен (по некоторым сведениям, до 600 - А.С.) индейцев, включая 30 манданов, и 3 декабря с развернутыми знаменами и под бой барабанов он вступил в главную деревню манданов.

В это время численность племени составляла около 15000 человек. У манданов было 9 постоянных поселений на реке Харт (Северная Дакота), состоявших из куполообразных индейских землянок, окруженных палисадом. Французы же привыкли, что индейцы живут в вигвамах и типи.

Верандри прошел около полутора тысяч километров и убедил себя, что почти достиг искомой реки. На разведку он отправил Луи-Жозефа: тот дошел до Олд-Кроссинг, где извилистая Миссури поворачивает на юго-запад, и принес добрую весть отцу.

В январе 1739 года Верандри, измотанный и в долгах, вернулся в Ла Рен. В июне 1740 года он уже был в Квебеке, намереваясь поправить свои финансовые дела, чтобы продолжить путешествия. Здесь он узнал, что его жена Мари-Анн, выступавшая как доверенное лицо в его долгое отсутствие, умерла в прошлом сентябре и была похоронена в часовне Сен-Луи церкви Нотр-Дам.

Боарнуа тепло его принял, поселил в собственном доме, а чтобы поддержать

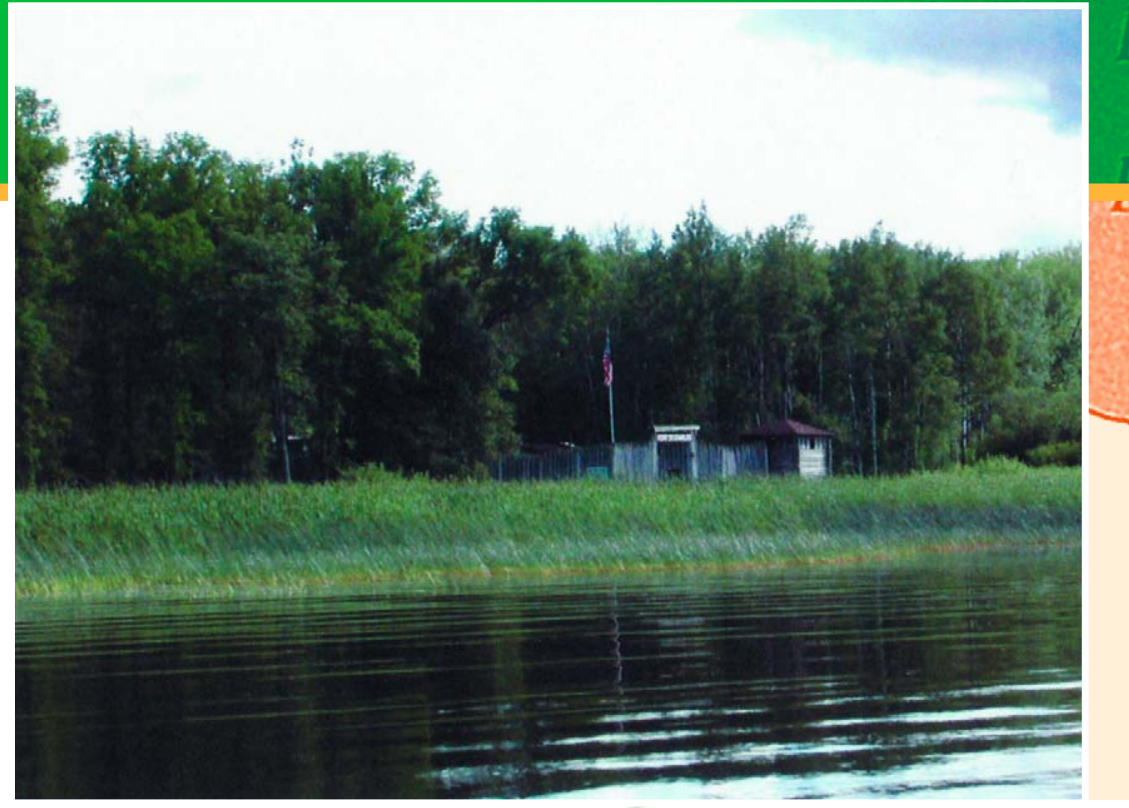

материально с июня 1741 года, когда истекала его договоренность 1735 года с монреальскими купцами, предоставил трехлетнюю монополию на торговлю во вновь основанных торговых постах.

В июне 1741 года в сопровождении отца Кокара Верандри в четвертый раз отправился на запад. В том же году его сын Пьер вышел из форта Ла Рен и отправился на юг, он добрался до двух испанских фортов, расположенных предположительно на территории штата Небраска.

Новым «штабом» Верандри стал форт Ла Рен, а осваивать озера Манитобы он поручил сыну Пьеру: в конце года тот, по поручению отца, приступил к строительству форта Дофин на озере Виннипегосис. В следующие два года его люди построили форт Бурбон
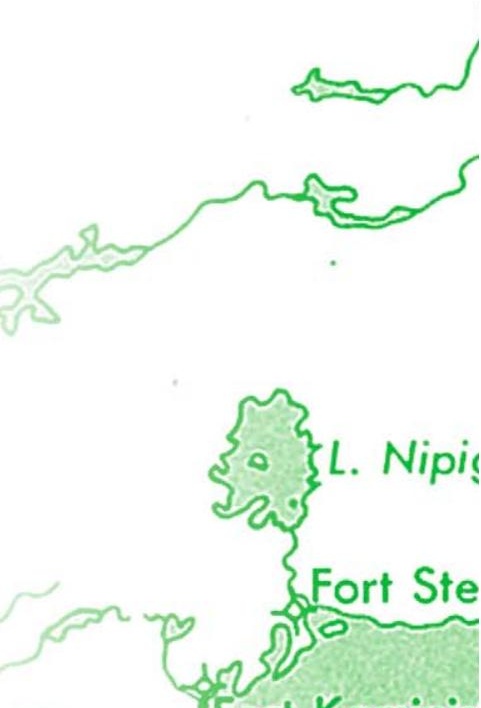

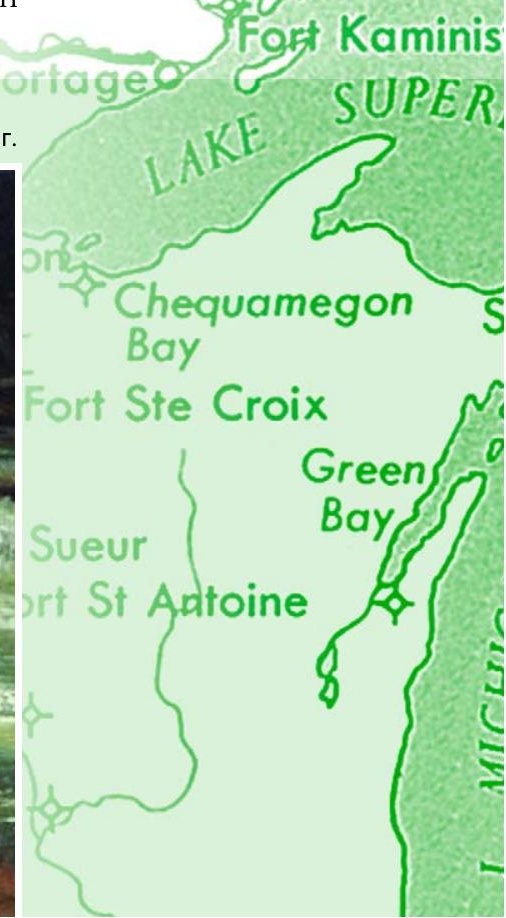

HISTORY illusluated 


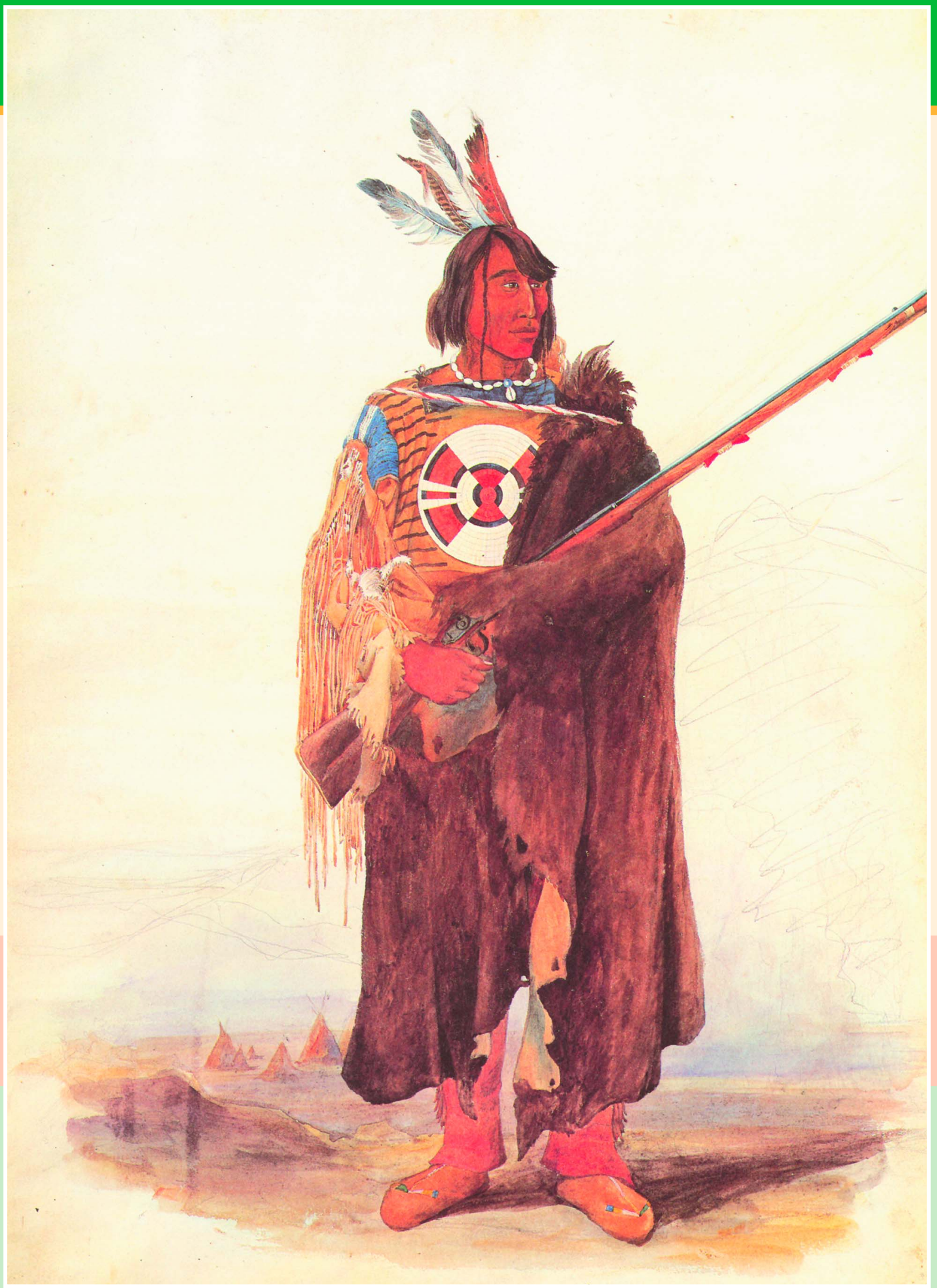

Индеец племени ассинибойнов. Худ. Карл Бодмер. 1830-е гг. Акварель. Джослиновский художественный музей, Омаха, Небраска. 


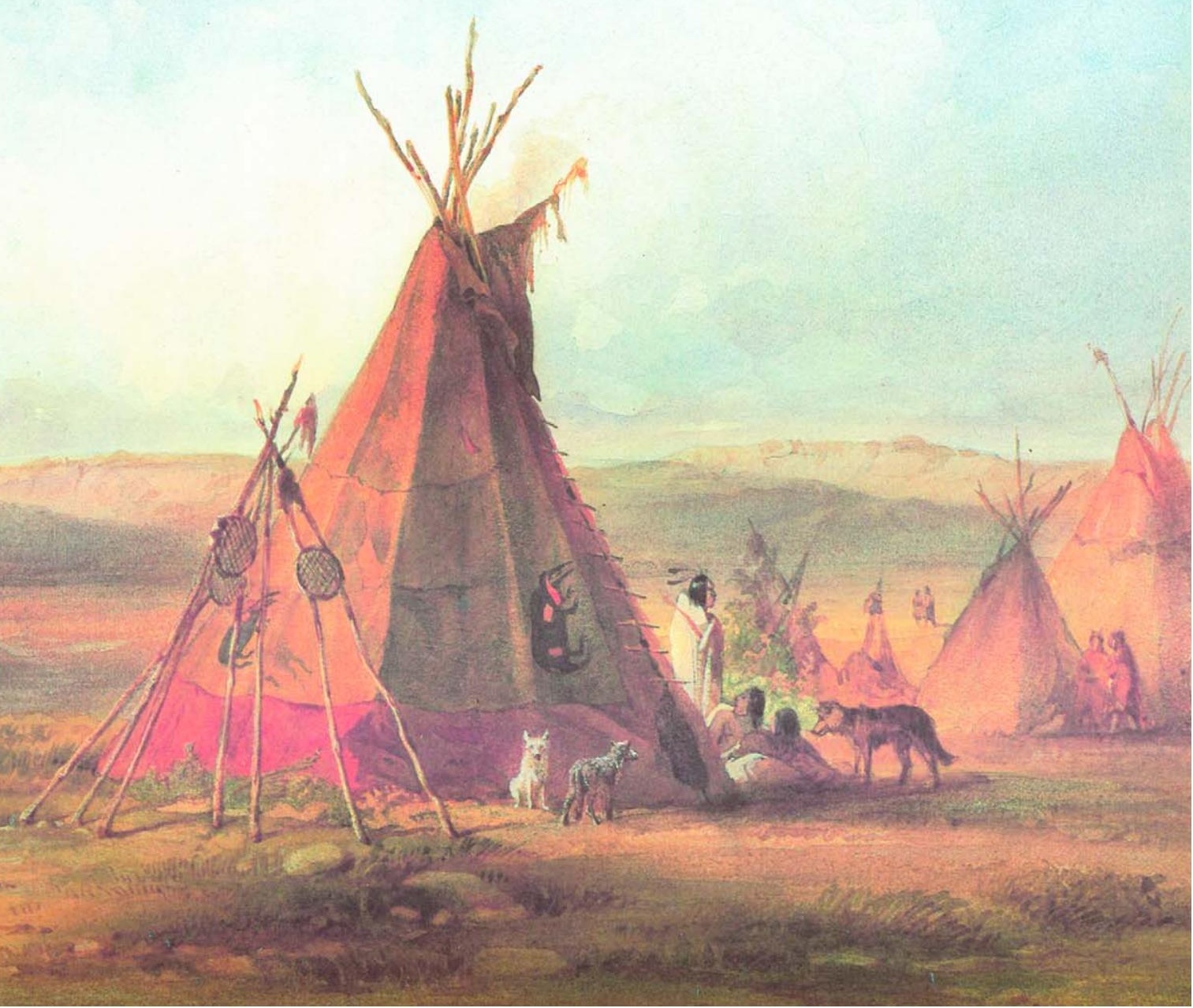

Лагерь ассинибойнов. Худ. Карл Бодмер. 1830-е гг. Акварель. Джослиновский художественный музей, Омаха, Небраска.

к северо-западу от озера Винниипег и форт Паскиа (или Паскуа) к северо-западу от озера Сидар, у слияния рек Каррот, Паскиа и Саскачеван.
После этого ассинибойнам уже не нужно было везти меха к Гудзонову заливу к англичанам, зато Морепо окончательно утвердился в торговых намерениях Верандри.

Боарнуа не соглашался, но воля начальства была ясна. Не дожидаясь отстранения, Верандри в 1743 г. подал в отставку. Он поселился в колонии, вращался в тамошнем обществе, вел свои дела (благо сыновья оставались на западе) и ухаживал за Эстер Сайе, вдовой Пьера де Лестажа, одного из богатейших купцов. 


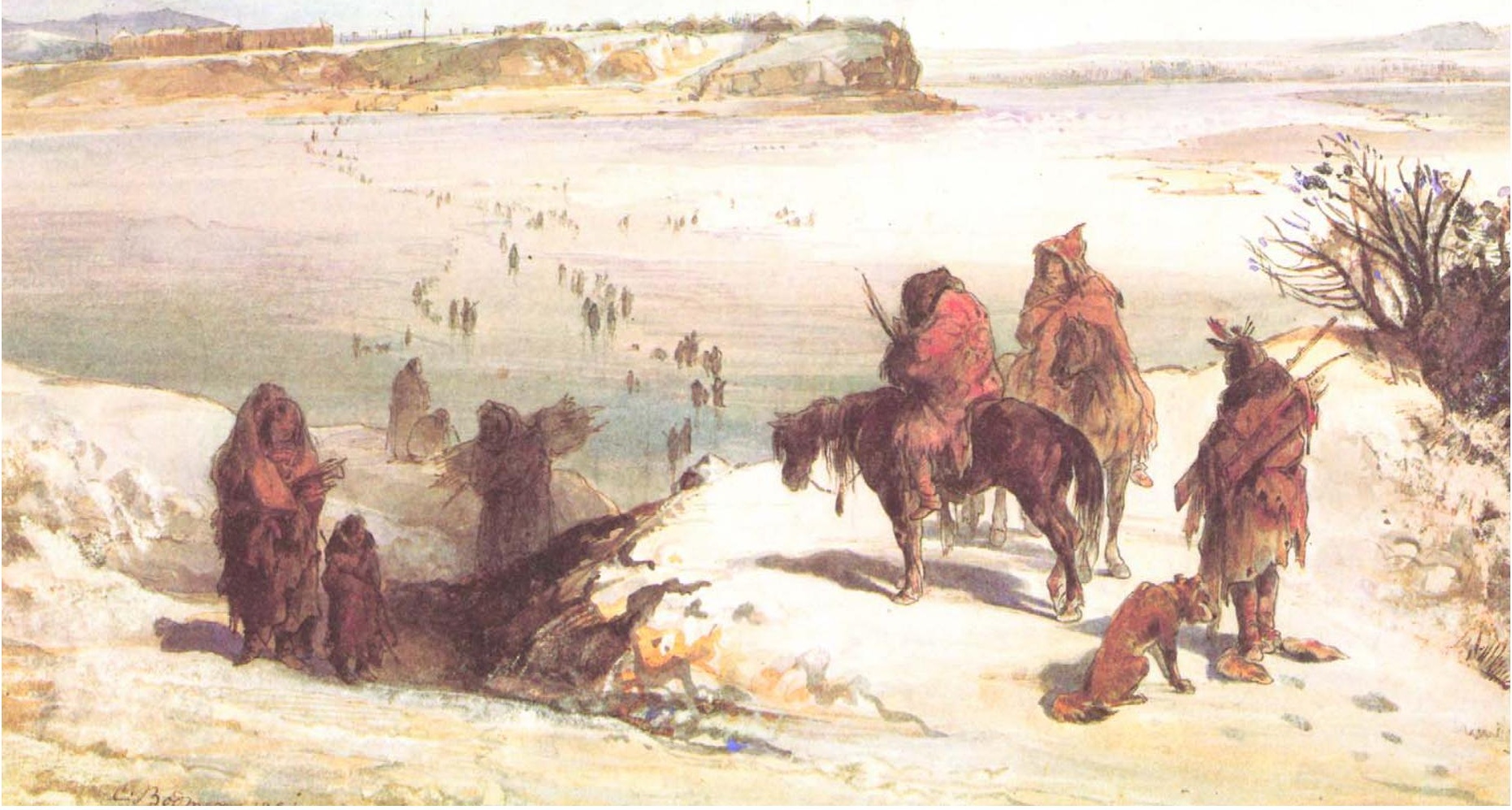

В 1742 году он писал Боарнуа, что предприятие было бы успешнее, если бы вместо Верандри и его сыновей этим занималась бы пара офицеров, которым бы Верандри платил по 3000 ливров. Боарнуа не согла- шался, но воля начальства была ясна. Не дожидаясь отстранения, Верандри в 1743 году подал в отставку. Он поселился в колонии, вращался в тамошнем обществе, вел свои дела (благо сыновья оставались на западе)

\section{В 1744-1746 гг. над возведенными по указанию Верандри фортами начальствовал Никола-Жозеф де Нуаелль де Флёримон, который посчитал нужным оставить молодых Вареннов на своих местах. Так, Луи-Жозеф Готье стал начальником форта Каминистикиа.}




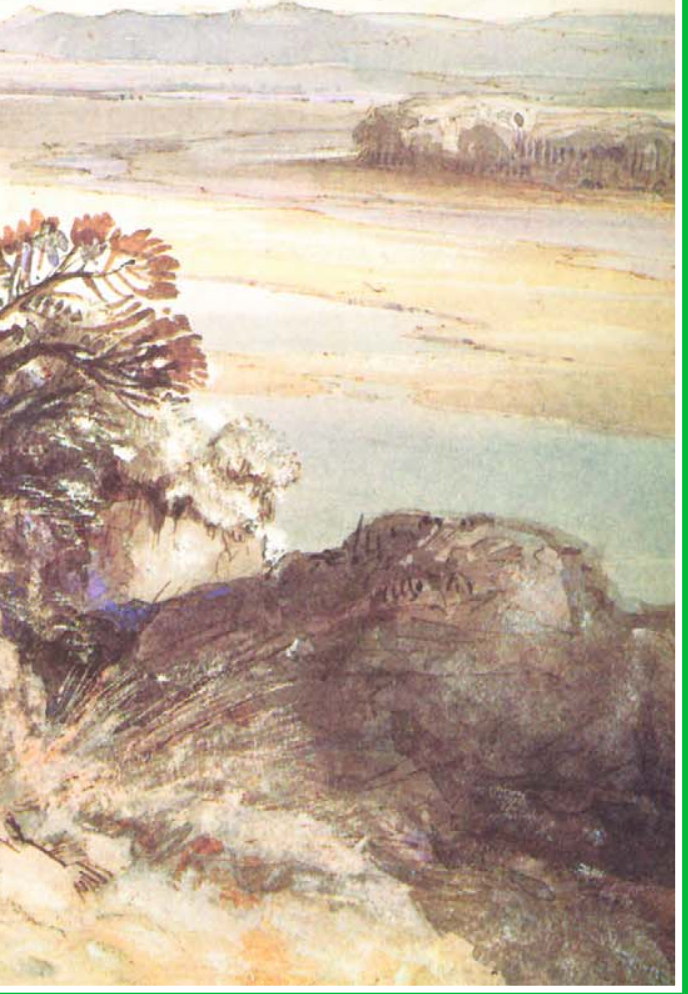

Ми-Тутта-Ханг-Куск, деревья манданов. Худ. Карл Бодмер. 1830-е гг. Акварель. Джослиновский художественный музей, Омаха, Небраска

Предметы материальной культуры $\Rightarrow$ манданов. Худ. Карл Бодмер. 1830-е гг. Акварель. Джослиновский художественный музей, Омаха, Небраска.

1. Деревянная дубинка; 2. Булава;

3. Арапник из оленьего рога; 4. Нож из камня; 5. Ковш из рога; 6. Обруч и палка для игры; 7. Стегоступы.

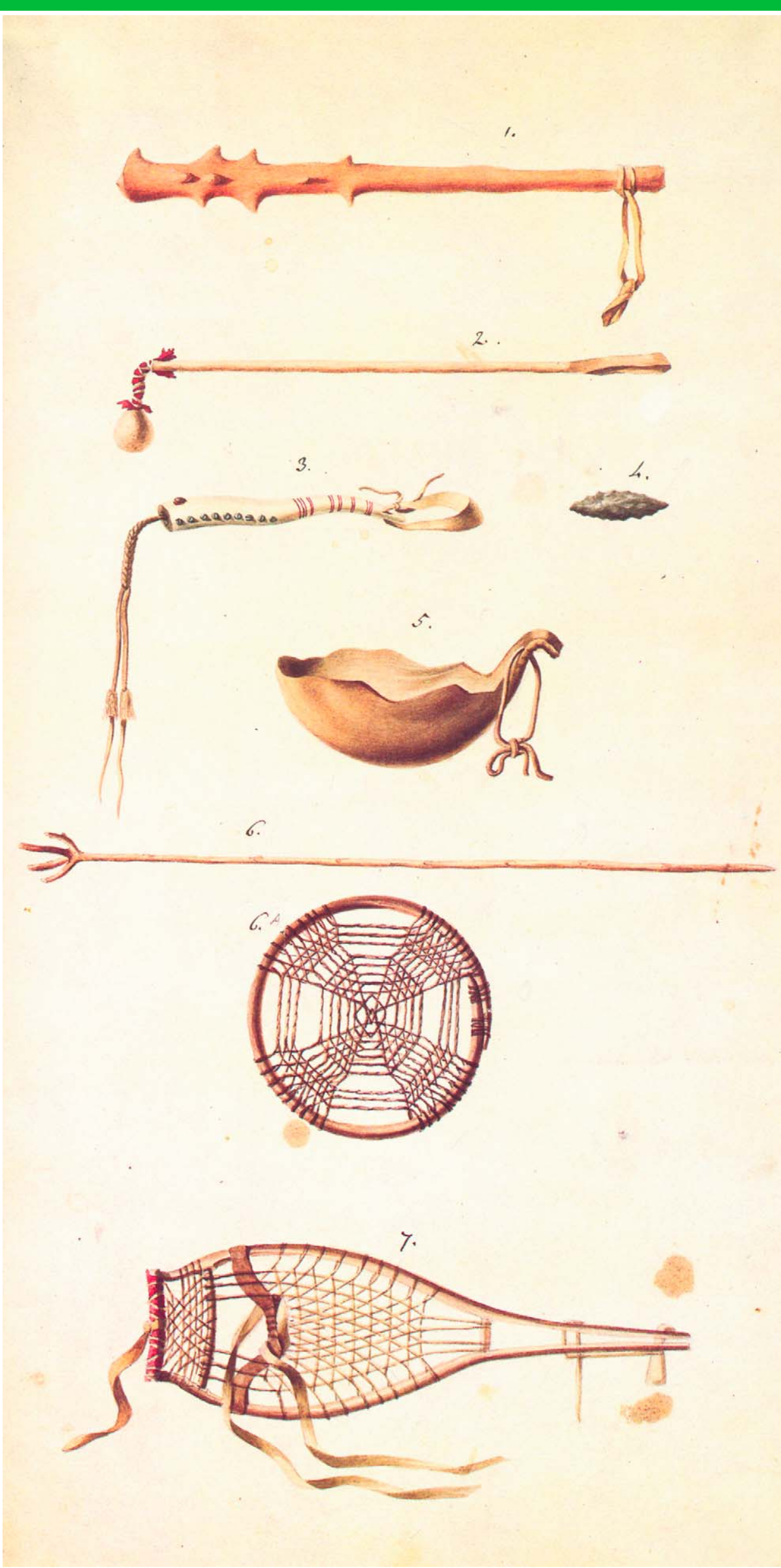




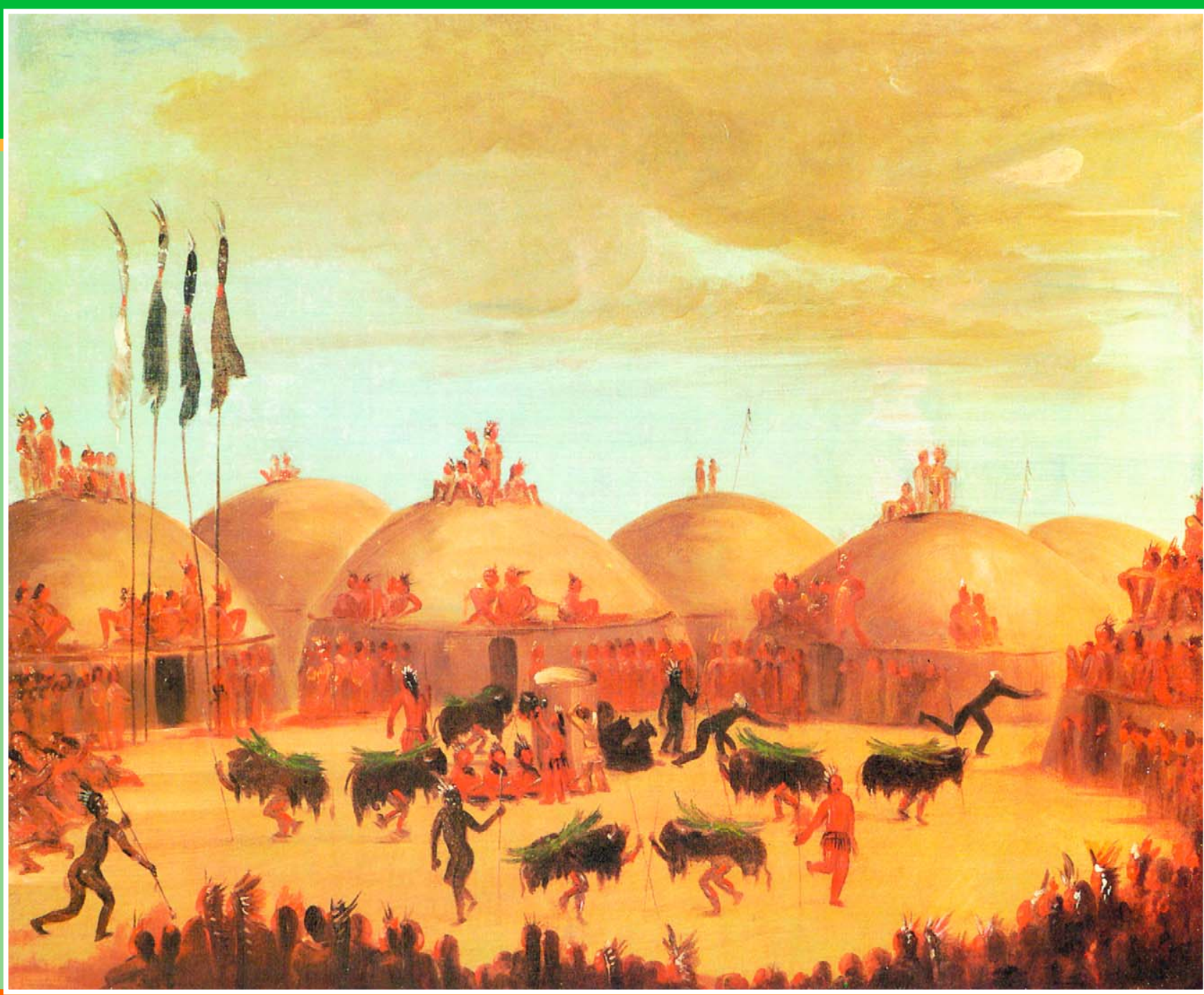

Танец буйвола у майданов. Худ. Карл Бодмер. 1832 г. Коллекция Анскуц, Денвер. и ухаживал за Эстер Сайе, вдовой Пьера де Лестажа, одного из богатейших купцов.

Не забывал он и о своем добром имени. В докладной записке Морепо от 1744 года Верандри писал, что колония извлекла тройную выгоду от его действий на западе: «Разве то, что мое предприятие дало многим людям средства к существованию, рабов ${ }^{6}$, которые поступают в колонию, имеха , ранее уходившие к анг-

Варенны жили в бедности. Пьер вновь поступил на военную службу и умер в Квебеке в 1755 г. Луи-Жозеф недолго начальствовал над западными торговыми постами, потом решил вернуться во Францию, но 15 ноября 1761 г. его судно «Огюст» пошло ко дну возле острова Кейп-Бретон. Последним ушел из жизни Франсуа, именовавший себя господином Дю Трамбле.

личанам, ничего не стоит?» Министр неохотно присвоил ему звание капитана, а Боарнуа сделал его начальником стражи.
В 1744-1746 годах над возведенными по указанию Верандри фортами начальствовал Никола-Жозеф де Нуаелль де Флёримон, который

${ }^{6}$ Ла Верандри занимался и работорговлей. В донесении губернатору Богарнуа от 26 мая 1742 года о. Клод-Годфруа Кокар (1706-1765 г2.) сообщал, что кри и ассинибойны в ходе четырехдневной битвы разгромили равнинных сиу, убили 70 человек, не считая женщин и детей, и захватили столько пленных, что они растянулись на четыре арпана (240м.) 


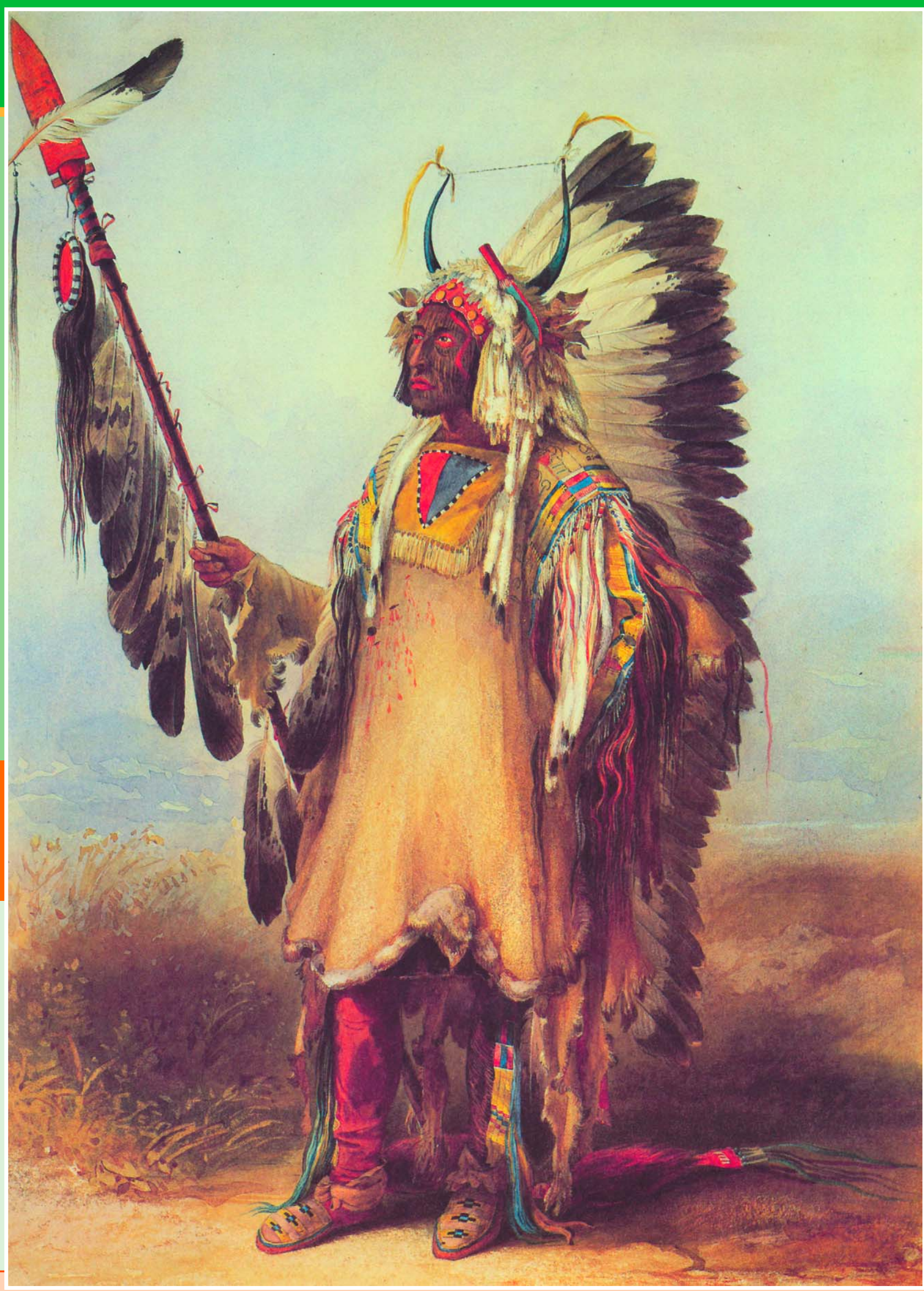

Мато-Топе, вождь манданов. Худ. Карл Бодмер. 1830-е гг. Акварель. Джослиновский художественный музей, Омаха, Небраска. 


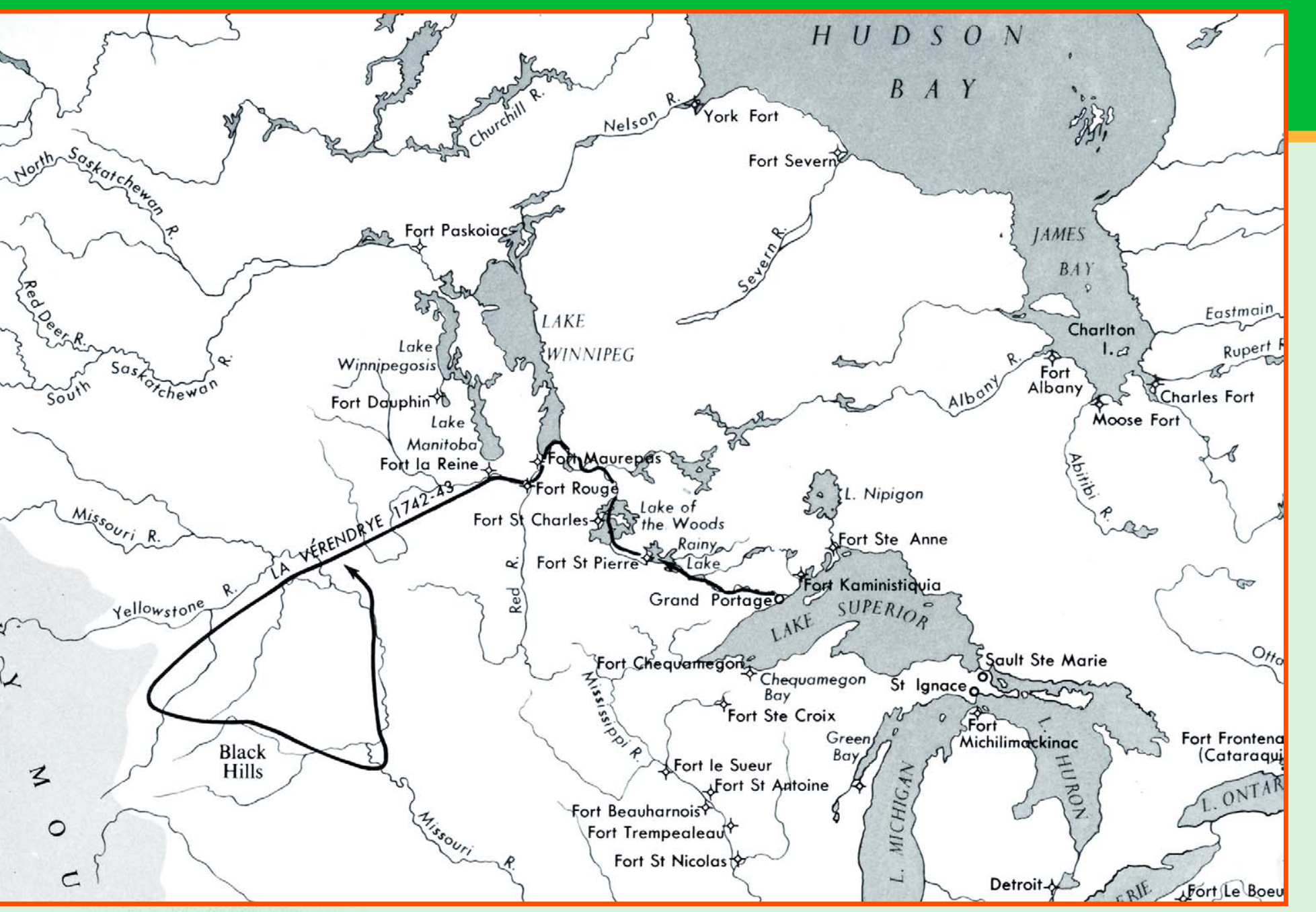

Маршрут путешествия братьев Верандри 1742-1743 гг.

посчитал нужным оставить молодых Вареннов на своих местах. Так, Луи-Жозеф Готье стал начальником форта Каминистикиа.

В 1746 году Верандри восстановили в должности. Обследовав западные форты в 1747 году, он увидел, что Ла Рен разрушился (несколько лет спустя его сожгли), а форт Морепо сожгли индейцы. У него был готов новый план: с конца апреля 1742 до начала июля 1743 года его сыновья Луи-Жозеф и Франсуа прошли на юго-запад через страну манданов и убедились, что моря в тех краях нет (они дошли и дальше, до Южной Дакоты или даже Вайоминга и видели отроги Скалистых гор). Ранее, в 1739-1740 годах Луи-Жозеф дошел до развилки реки Саскачеван (обозначенной на картах Верандри как «река Бланш»). Верандри планировал

\section{«Это была последняя французская экспедиция,} ставившая задачей поиски водного пути к Тихому океану. Подобные попытки стали казаться бессмысленными, власти воздерживались от их субсидирования, и не прошло и двух десятилетий, как французские владения в Америке попали в руки англичан...» - писал Реймонд Рамсей 


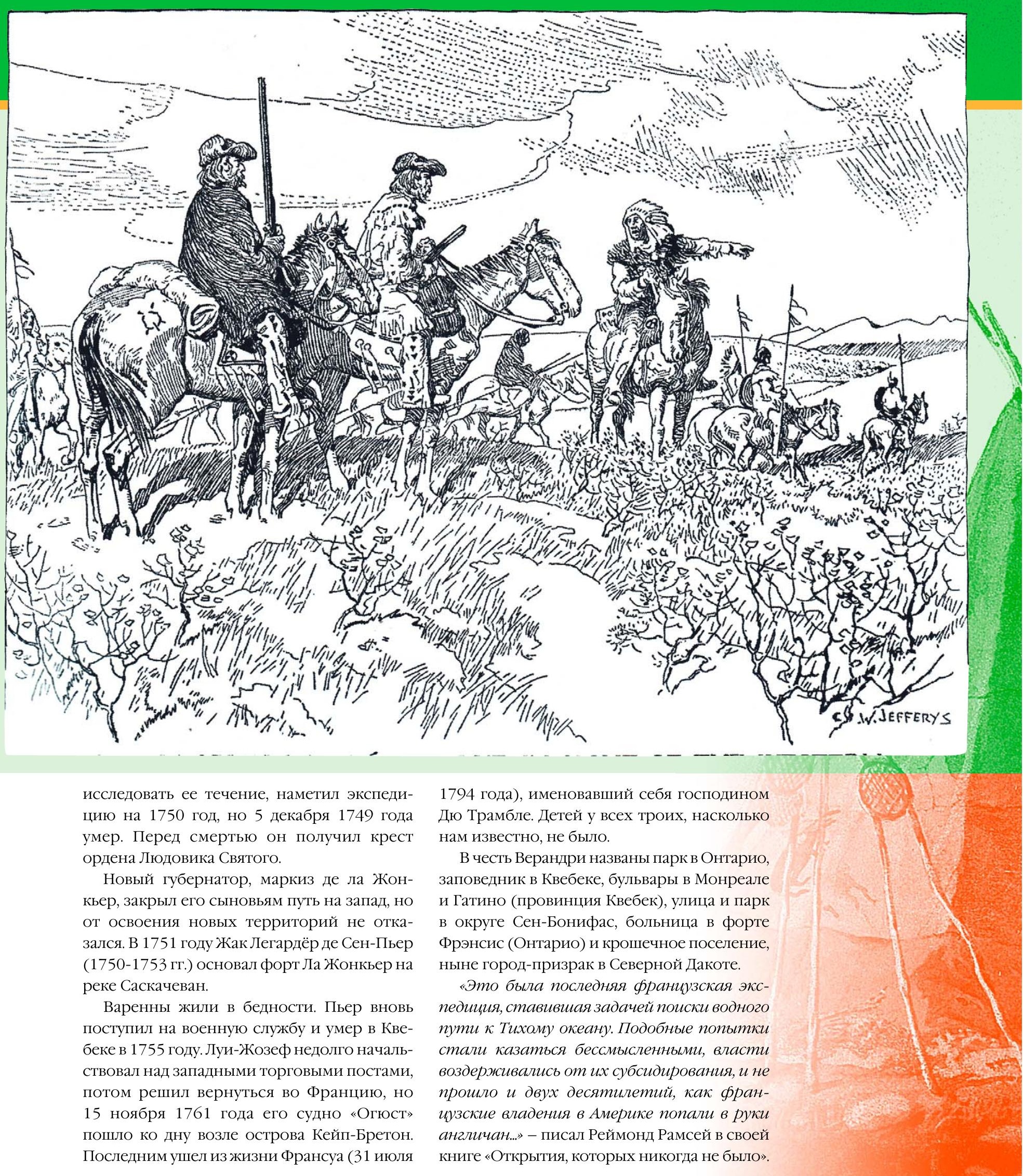

Bверху:

Братья Верандри видят Скалистые горы, 1 января 1743 года.

Рисунок Чарльза Уильяма Джеффериза. 